\title{
Spain: 2006 Article IV Consultation-Staff Report; Staff Supplement; Public Information Notice on the Executive Board Discussion; and Statement by the Executive Director for Spain
}

Under Article IV of the IMF's Articles of Agreement, the IMF holds bilateral discussions with members, usually every year. In the context of the 2006 Article IV consultation with Spain, the following documents have been released and are included in this package:

- $\quad$ the staff report for the 2006 Article IV consultation, prepared by a staff team of the IMF, following discussions that ended on March 21, 2006, with the officials of Spain on economic developments and policies. Based on information available at the time of these discussions, the staff report was completed on May 23, 2006. The views expressed in the staff report are those of the staff team and do not necessarily reflect the views of the Executive Board of the IMF.

- a supplement to the staff report of June 7, 2006 updating information on recent developments.

- $\quad$ a Public Information Notice (PIN) summarizing the views of the Executive Board as expressed during its June 12, 2006 discussion of the staff report that concluded the Article IV consultation.

- $\quad$ a statement by the Executive Director for Spain.

The documents listed below have been or will be separately released.

Financial System Stability Assessment

Financial Sector Assessment Program—Detailed Assessments and Technical Notes

Selected Issues Paper

The policy of publication of staff reports and other documents allows for the deletion of market-sensitive information.

To assist the IMF in evaluating the publication policy, reader comments are invited and may be sent by e-mail to publicationpolicy@imf.org.

Copies of this report are available to the public from

International Monetary Fund • Publication Services

$70019^{\text {th }}$ Street, N.W. • Washington, D.C. 20431

Telephone: (202) 623-7430 • Telefax: (202) 623-7201

E-mail: publications@imf.org • Internet: http://www.imf.org

Price: $\$ 15.00$ a copy

\section{International Monetary Fund Washington, D.C.}



INTERNATIONAL MONETARY FUND

\section{SPAIN}

\section{Staff Report for the 2006 Article IV Consultation}

Prepared by the Staff Representatives for the 2006 Consultation with Spain

Approved by Michael Deppler and G. Russell Kincaid

May 23, 2006

- $\quad$ The 2006 Article IV consultation discussions were held in Madrid and Barcelona during March 8-21. The staff team comprised Messrs. Leipold (head), Escolano, Catalán, and Lama (all EUR), and Ms. Albino-War (FAD). Ms. Brenner (MFD) joined the mission to discuss the FSAP conclusions. Mr. Moreno (OED) also participated in the meetings.

- $\quad$ The mission met with Minister of Economy and Finance Solbes, Bank of Spain Governor Caruana, other senior officials; Congress's Economic and Budget Committee; officials of the Autonomous Government of Catalonia; employers and labor unions; and representatives of the opposition, private sector, and academics. Drafts of the Special Issues papers were discussed in seminars. The authorities promptly released the mission's concluding statement (http://www.imf.org/external/np/ms/2006/032106.htm).

- $\quad$ Mr. Rodríguez Zapatero's socialist government is at mid-term of its four-year tenure, with the next elections expected for 2008. It depends on the parliamentary support of small left-wing and regional parties.

- $\quad$ Spain maintains an exchange system free of restrictions on payments and transfers for current international transactions, except for those maintained solely for the preservation of national or international security, and notified to the Fund under Decision No. 144-(52/51); Spain has accepted the obligations of Article VIII, Sections 2, 3, and 4 (Appendix I). 
Contents Page

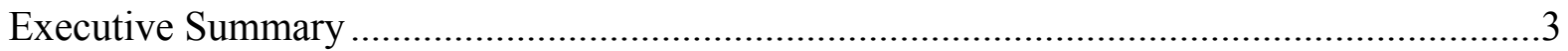

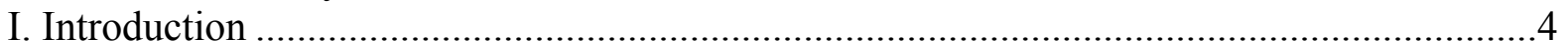



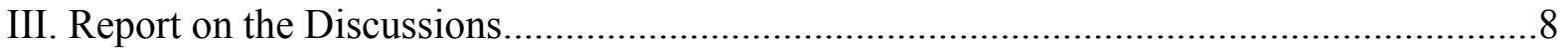

A. Outlook: A Bright Near-Term but Clouds Further Out .......................................9

B. Dampening Demand - The Task of Fiscal Policy..............................................13

C. Maintaining Fiscal Stability in the Medium and Long Term...............................16

D. Creating a More Competitive Spain—Product and Labor Market Reforms ..........20

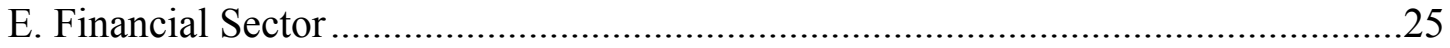

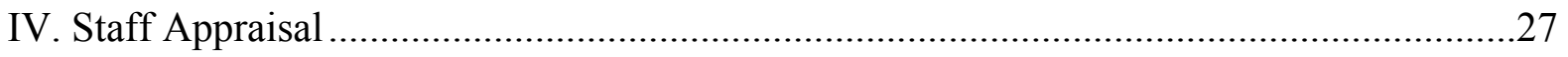

Boxes

1. Fund Policy Recommendations and Implementation ............................................

2. Spain's Competitiveness: What is the Evidence? .................................................... 11

3. Fiscal Policy: Can it Help Attenuate Imbalances?.................................................. 15

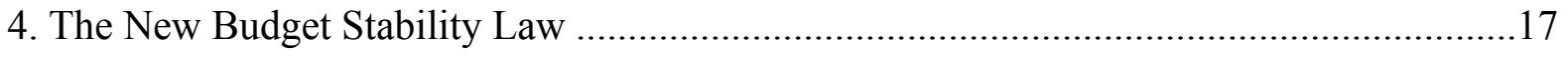

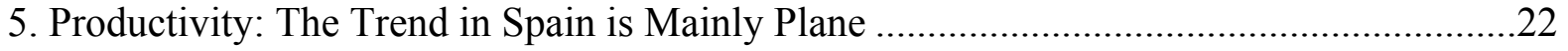

6. FSAP_-Selected Main Recommendations .....................................................................26

Tables

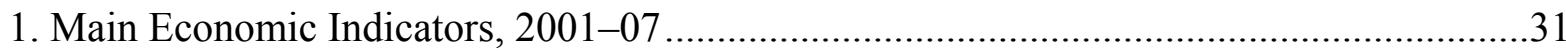

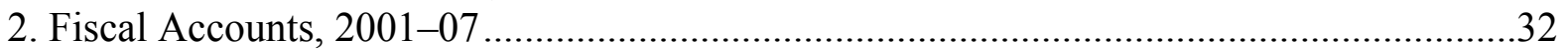

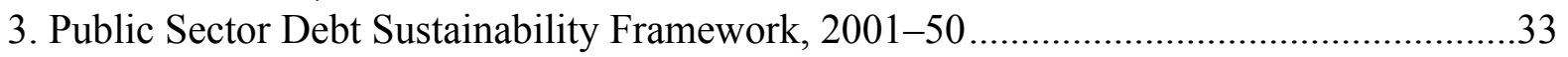

4. Indicators of External and Financial Vulnerability, 2000-05 .......................................34

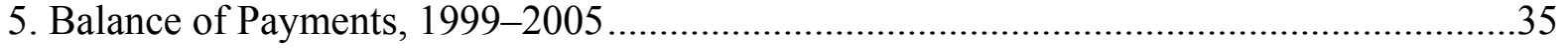

6. Medium-Term Projections of the Balance of Payments .................................................36

Figures

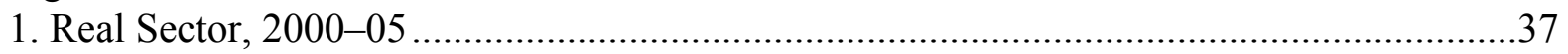

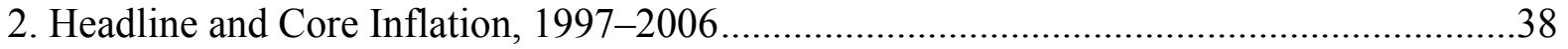

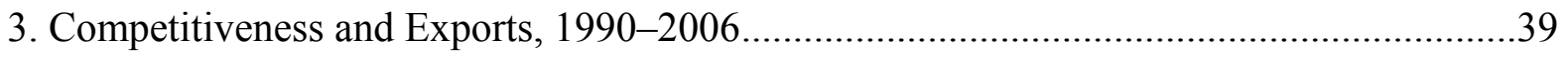



5. Financing of the Current and Capital Account Deficits .................................................. 41



Appendices

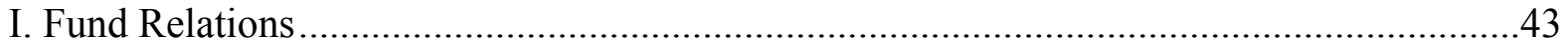

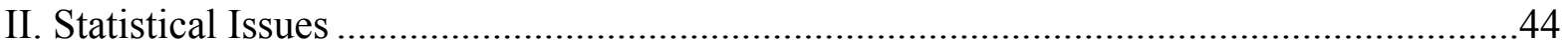




\section{EXECUTIVE SUMMARY}

\section{Background}

Output growth (3.4 percent) and employment creation remained impressive in 2005 -but imbalances have intensified. Domestic demand, while decelerating mildly, has driven growth - with the current account deficit widening to $7 \frac{1}{2}$ percent of GDP and the inflation differential with the euro area rising to $1 \frac{3 / 4}{4}$ percentage points. Buoyed by revenues, the general government recorded a surplus of 1.1 percent of GDP in 2005 and public debt is low-but spending is ratcheting up.

\section{Policy Discussions}

Short-term growth prospects are good (3.3 percent in 2006), but the medium-term outlook is clouded by accumulated imbalances and competitiveness losses. A smooth rebalancing (helped by firming euro-area activity and rising interest rates) underlies both official and staff central projections. The external deficit, however, is expected to remain large. Adverse risks stem from high net external liabilities (46 percent of GDP) reflecting household indebtedness (110 percent of disposable income), which might prompt pronounced balancesheet and real estate valuation adjustments, and a protracted period of depressed employment and activity. The discussions were thus centered on the role of fiscal and structural policies in forestalling such scenarios.

The authorities were confident that appreciable fiscal surpluses would continue into 200607, but saw limited scope for countercyclical spending cuts, advocated by staff, beyond tight implementation of current plans. Revisions to the fiscal framework will introduce cyclical flexibility, while providing greater leeway to regional governments. In the absence of effective enforcement mechanisms, transparency will be key. Regional financing arrangements are being reviewed, and healthcare and pension reform also remain on the agenda.

The authorities have formulated an ambitious and detailed structural reform agenda, articulated in their National Reform Program, to improve the productivity and dynamism of the economy. Fostering productivity will require an early focus on deregulating and opening sheltered sectors to competition - including sensitive areas (energy). Protracted labor market negotiations have led to an agreement that aims to reduce the extensive use of temporary employment, while leaving the provisions of regular contracts unchanged.

The recently concluded FSAP found a highly dynamic and competitive financial sector under strong prudential supervision and regulation. The authorities were broadly receptive of the FSAP's recommendations to exercise vigilance with respect to developments in the mortgage market; bolster the independence of financial sector supervisors; improve governance and market discipline of savings banks; and adopt a conservative treatment of financial institutions' industrial participations under Basel II. 


\section{INTRODUCTION}

1. The Spanish economy is enjoying a prolonged expansion. In 2005, Spain's economy grew by 3.4 percent and created more than 60 percent of all new jobs in the euro area. This remarkable expansion has raised income levels to the EU-25 average and reduced the unemployment rate by $12 \frac{1}{2}$ percentage points since 1996, even while absorbing exceptionally large immigration flows. Activity has been supported by strong domestic demand growth, which has outpaced that of GDP since mid2002. Sustained fiscal consolidation efforts and robust growth turned a budget deficit of 5 percent of GDP in 1996 into a surplus of over 1

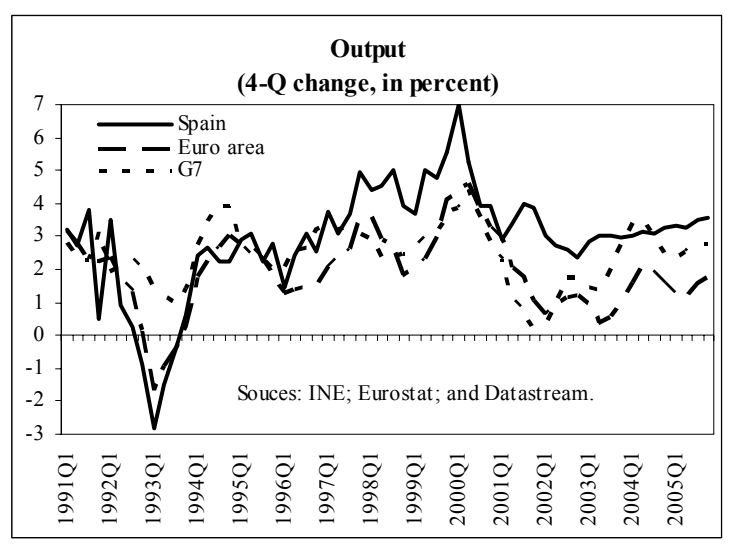
percent of GDP in 2005, while public indebtedness was cut from 67 to 43 percent of GDP. The past decade also witnessed an impressive expansion of the financial sector's presence domestically and abroad-Spanish institutions' financial assets increased from about 220 percent of GDP in 1996 to 330 percent in 2005.
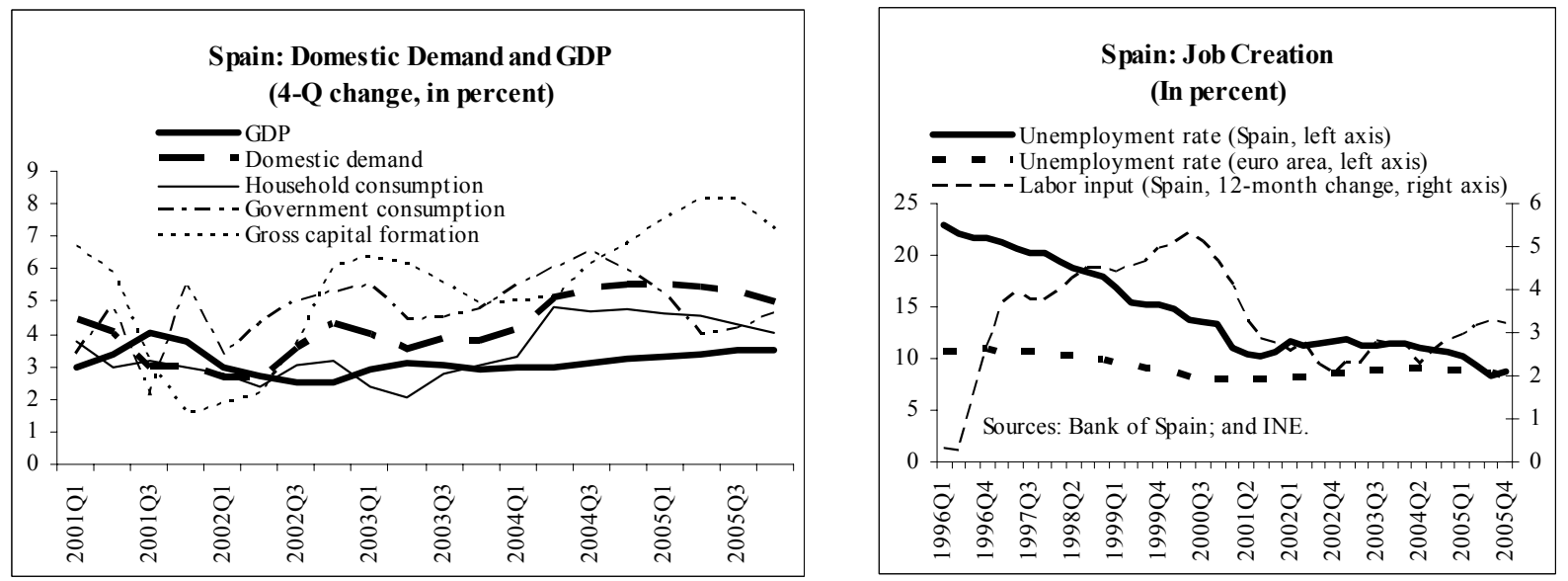

\section{Growth has however become increasingly lopsided, as reflected in a widening} inflation differential and rising current account deficit. Domestic demand has boomed, supported by employment and income gains; wealth effects from rising real estate and equity prices; and rapid credit expansion in the midst of negative real interest rates. Propelled by mortgage credit growth of 25 percent in 2005, household indebtedness reached over 110 percent of disposable income. While the authorities have allowed the full play of fiscal revenue stabilizers and maintained a contractionary budgetary stance for several years (albeit less so in 2005), this has been insufficient to offset very loose liquidity conditions. The inflation differential with the euro area thus reached 13/4 percentage points in 2006:Q1, and the 2005 current account deficit rose to $7 \frac{1}{2}$ percent of GDP - the second largest in absolute 
terms in the world. While Spain's oil dependency, the weakness of its traditional export markets, and its advanced cyclical position have all played a role, the current account deterioration also reflects a steady real exchange rate appreciation and related export-market share losses. As documented in the authorities' National Reform Program under the Lisbon Agenda, the erosion of competitiveness goes beyond cyclical factors: structural factors include lackluster productivity growth and significant rigidities in product and labor markets.

\section{While a smooth and gradual rebalancing underlies both official and staff} projections, there are important risks. The main one is a continuation of the current unsustainable pace in domestic spending that is followed by pronounced adjustments in household balance sheets and real estate valuations, entailing a protracted period of depressed employment and activity. The discussions were thus centered on the role of fiscal and structural policies in forestalling such scenarios.

\section{BACKGROUND}

\section{In 2005, domestic demand growth again outstripped that of GDP and net} exports increased their drag on output. Consumption and construction investment maintained a rapid pace, together contributing some 4 percentage points to growth - although exhibiting a mild deceleration over the year. In addition, the long-awaited recovery in equipment investment got underway, possibly hastened by expectations of tighter financing conditions. For its part, the drag on growth from net exports reached some 2 percentage points, as import penetration and the erosion of export market shares intensified. Housing wealth gains remained a key buttress of demand, although real house price growth decelerated further, from a peak of $15 \frac{1}{2}$ percent in 2003:Q2 (seasonally adjusted, q-o-q annualized) to 81/4 percent in 2006:Q1. Reflecting this pattern of

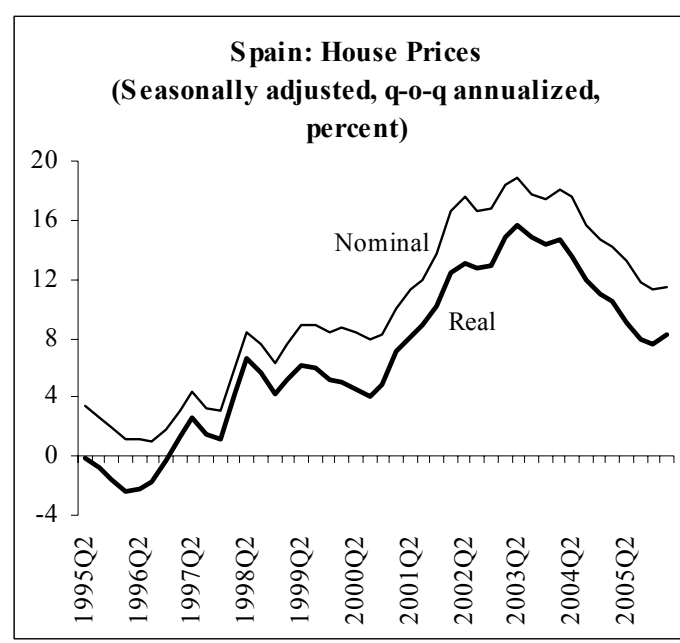
demand, the expansion was concentrated in the services, construction, and energy sectors; sectors exposed to external competition, in contrast, experienced little growth. 
5. High inflation persisted through 2005 and accelerated at the turn of the year, reflecting the passthrough of fuel prices and backward price indexation of wages.

Comparatively high oil dependency has resulted in a significant contribution of energy and transportation items to headline inflation. But core inflation also exceeded the euro area average by a widening margin (1.6 percentage points in 2006:Q1), reflecting the continued upward price drift in the sheltered services and retail sectors. Hourly labor costs have shown a decelerating trend despite substantial increases in the employment rate and reductions in unemployment, pointing to a decline in the NAIRU - underpinned by high immigration and growing female participation. Nevertheless, wages still increased faster than the euro area average, as did unit labor costs. Price indexation clauses in collective wage contracts stand to sustain price pressures into 2006.
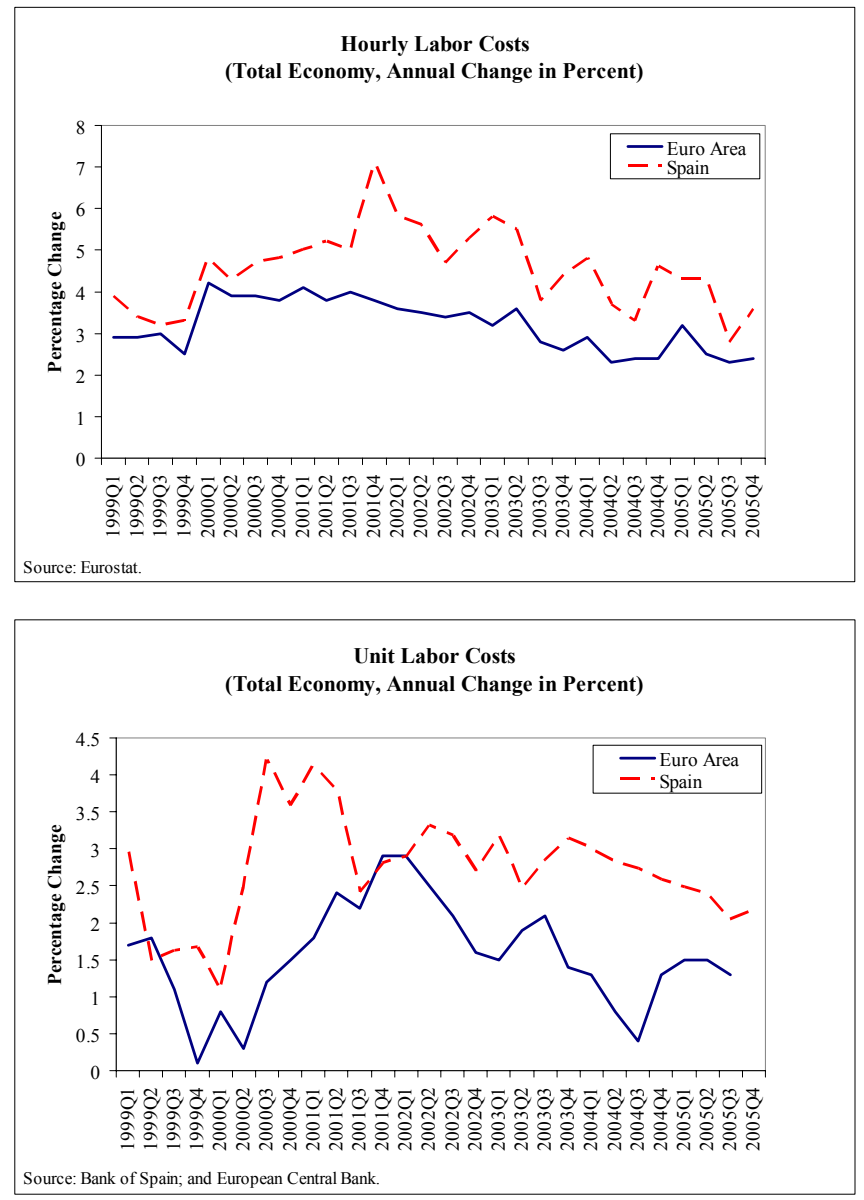

6. Liquidity conditions remain expansionary. Real lending rates are negative or close to zero, and both household and corporate credit grew at over 20 percent in the year to January 2006, spearheaded by mortgages and credit to real estate developers. There is little housing equity withdrawal, and nontraditional mortgages are still relatively rare, albeit developing quickly.
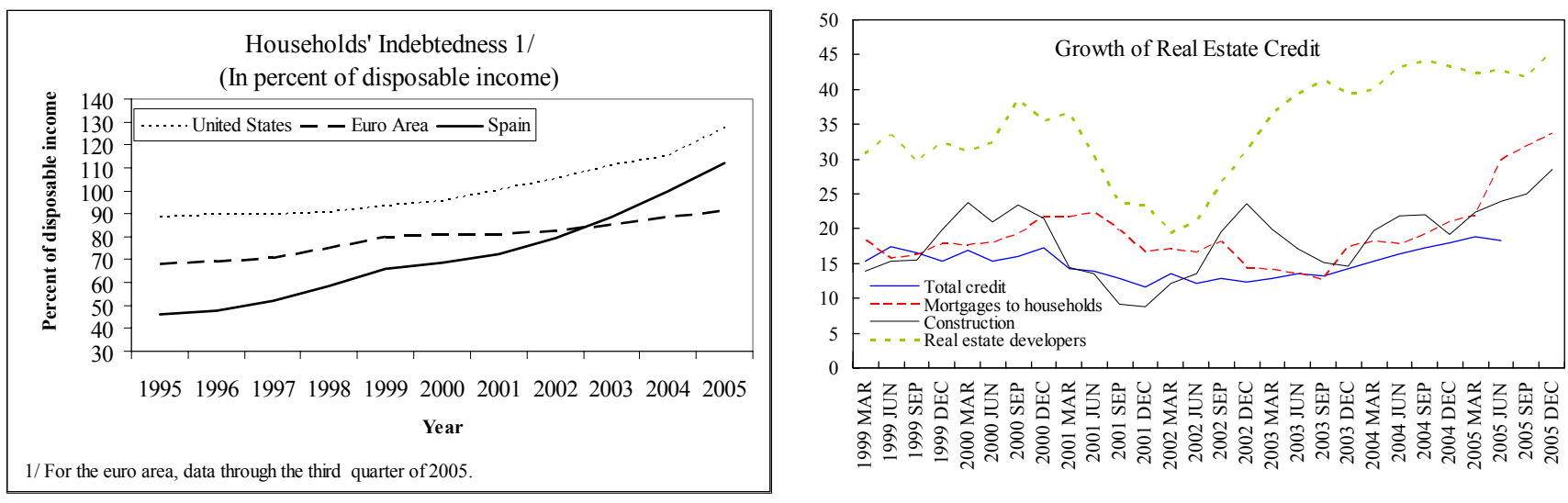
7. Mirroring the current account deterioration, the economy's net external liability position exceeded 46 percent of GDP in 2005-primarily associated with increased intermediation of foreign savings by financial institutions. Since the mid-1990s, the widening external deficit has reflected a decline in the savings-investment balance of the household and nonfinancial corporate sectors, only partly offset by an improving fiscal balance. ${ }^{1}$ Credit institutions and other financial intermediaries (e.g., structuredfinance vehicles), while presenting a financial surplus themselves, have met the increasing financing need of the nonfinancial private sector by issuing securities in euro-area markets. Net external borrowing by these two sectors amounted to 14 percent of GDP in 2005, mainly through mortgagebacked securities, of which Spain has become one of the largest EU issuers. In terms of gross external debt, while Spain's liabilities have a longer maturity and a lower public component than other comparable countries, its net international liability position is larger.
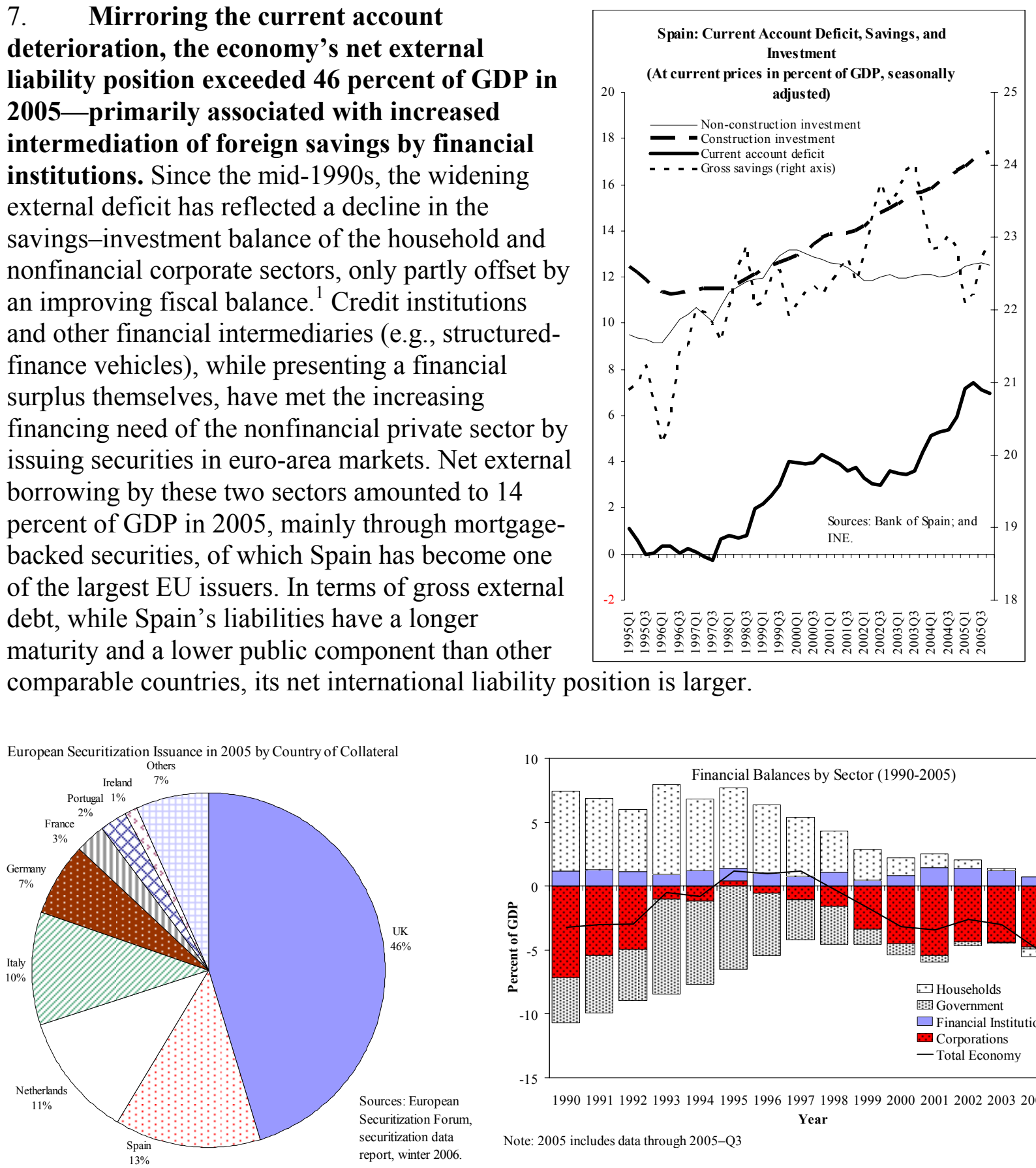

\footnotetext{
${ }^{1}$ While higher nonconstruction investment played some role in the second half of the 1990s, the recent deterioration of the current account has almost fully matched the increase in construction investment and cannot thus be attributed to an investment-driven catch-up process, such as that observed in some new EU members.
} 
International Comparison of International Investment Position (IIP) 1/

\begin{tabular}{|c|c|c|c|c|c|c|c|c|}
\hline & \multirow[t]{2}{*}{$\begin{array}{c}\text { Net IIP } \\
(\% \text { of GDP })\end{array}$} & \multicolumn{2}{|c|}{$\begin{array}{c}\text { Gross external debt } \\
\text { by maturity } \\
(\% \text { of total })\end{array}$} & \multicolumn{5}{|c|}{$\begin{array}{l}\text { Gross external debt by debtor } \\
(\% \text { of total })\end{array}$} \\
\hline & & Short term & Long term & Government & $\begin{array}{c}\text { Central } \\
\text { bank }\end{array}$ & $\begin{array}{c}\text { Credit } \\
\text { institutions } \\
\end{array}$ & $\begin{array}{c}\text { Other } \\
\text { sectors }\end{array}$ & $\begin{array}{c}\text { Companies } \\
2 / \\
\end{array}$ \\
\hline Germany & 8.1 & 31.9 & 68.1 & 23.6 & 0.3 & 56.5 & 8.4 & 11.3 \\
\hline France & 5.3 & 38.1 & 61.9 & 25.2 & 0.1 & 49.8 & 17.3 & 7.6 \\
\hline Italy & -18.1 & 32.9 & 67.1 & 50.2 & 0.0 & 29.9 & 17.4 & 2.4 \\
\hline Netherlands & -5.8 & 37.9 & 62.1 & 12.6 & 0.0 & 57.2 & 14.5 & 15.7 \\
\hline Belgium & 30.9 & 72.2 & 27.8 & 18.1 & 3.7 & 63.3 & 6.6 & 8.3 \\
\hline Finland & -12.1 & 26.9 & 73.2 & 30.6 & -0.1 & 34.6 & 17.7 & 17.3 \\
\hline Austria & -17.4 & 32.6 & 67.4 & 31.8 & 4.0 & 50.0 & 12.2 & 2.0 \\
\hline Ireland & -19.7 & 49.4 & 50.6 & 3.0 & 0.9 & 56.4 & 27.9 & 11.8 \\
\hline Greece & -73.6 & 27.7 & 72.3 & 63.0 & 5.4 & 22.8 & 8.4 & 0.4 \\
\hline Portugal & -69.7 & 41.6 & 58.4 & 24.0 & 5.4 & 52.9 & 13.5 & 4.3 \\
\hline Spain & -49.1 & 23.6 & 76.4 & 20.0 & 0.0 & 47.8 & 22.7 & 9.5 \\
\hline United States & -22.6 & 41.0 & 59.0 & 22.7 & 3.7 & 19.7 & 46.5 & 7.5 \\
\hline United Kingdom & -13.2 & 77.1 & 22.9 & 2.7 & 0.4 & 59.7 & 28.9 & 8.3 \\
\hline
\end{tabular}

\section{REPORT ON THE DISCUSSIONS}

8. With immediate growth prospects jointly seen as positive, the discussions focused on the role of economic policies in averting adverse scenarios stemming from accumulated imbalances and competitiveness losses and on financial sector policies in light of FSAP recommendations. Spain's economic policies have for several years been largely in line with Fund policy advice (Box 1), and on this occasion too there was a broad convergence of views on the diagnosis and policy requirements. Nuances centered on the extent to which competitiveness losses were already a manifest concern, and consequently on the degree of urgency and ambition of the recommended response. This also reflected the authorities' assessment of the measures' feasibility, in light of the government's emphasis on a consensual approach and its minority position in Parliament. Furthermore, the authorities were doubtful of the proposition that the ongoing economic expansion provided a propitious environment for reform since "good times" diminish the perceived need for change. In this setting, and with the current legislature ending in early 2008, staff attempted to impart a greater sense of policy urgency, including in its outreach activities vis-à-vis parliamentarians, trade unions, employers, regional representatives in Catalonia, and academics. 


\section{Box 1. Fund Policy Recommendations and Implementation}

Policies for several years have been broadly in line with Fund advice - notably in terms of a stability-oriented fiscal policy framework and structural reforms in labor and product markets. On the former, pending steps to enhance the cyclical sensitivity of the fiscal framework are consistent with Fund advice, though improvements in fiscal transparency still fall short of requirements - particularly at the subnational level, where the new Budgetary Stability Law also provides a greater degree of leeway than advised by the Fund.

The authorities' structural reform agenda is consistent with Fund analyses and recommendations, and Spain has generally taken a liberal and open position on EUwide issues - though it too appears prone to some protective reflexes as the internal market approaches more sensitive areas (e.g., energy). Also, labor market reform has been insufficiently bold, and that of the pension system continues to be delayed. The authorities have consistently maintained strong financial sector prudential policies, as recognized also in this year's positive FSAP findings.

\section{A. Outlook: A Bright Near-Term but Clouds Further Out}

9. Immediate growth prospects remain upbeat. Staff and official projections broadly coincide. Growth is projected to moderate slightly to some 3.3 percent in 2006 and to 3.2 percent in 2007. A slowdown in retail sales, consumer durables, house prices, and other leading indicators all suggest a prospective domestic demand softening. On this basis, consumption and residential investment are expected to decelerate in 2006, with the housing market gradually cooling off. Business investment, while remaining high as a proportion of GDP, should plateau in response to higher capital costs. At the same time, the gathering euro-area recovery is expected to reduce the drag from the external sector. Indeed, the authorities noted that firming euro-area interest rates and strengthening external demand was the ideal combination for a rebalancing of Spanish growth. Staff agreed, though euro-area interest rates are unlikely to rise sufficiently from the Spanish economy's standpoint. The inflation forecast for 2006 remains close to $3 \frac{1}{2}$ percent, well in excess of the euro area average.

10. The authorities' Stability Program, and staff, project that external imbalances would remain large over the medium term. While the authorities envisage a continuation of the export recovery that started in the second half of 2005, the observed high elasticity of imports coupled with the projected growth in final demand point to a further steady deterioration in net exports. Increased interest payments and immigrant remittances, and the envisaged decline in EU transfers, will additionally raise the economy's financing needs to above 8 percent of GDP by 2008. Staff stressed that a prolonged external imbalance would expose the economy to interest rate risk and other shocks and would be unsustainable over the long term. 


\section{The authorities expect their competitiveness-enhancing policy agenda to} eventually reverse this trend, while recognizing that such a turnaround would take time to unfold. In this context, they also pointed to the role played by the intertemporal profile of saving and investment, whereby the observed increase in the current account deficit may have inter alia been brought about by a temporary excess of planned private investment with respect to aggregate savings. The current level of net external liabilities could thus be smoothed in the future through some combination of real exchange rate depreciation and a gradual moderation of domestic absorption. In principle, they noted, there would be no need for an abrupt adjustment. They also pointed out that EMU membership drastically expanded the economy's capacity to finance external deficits - inter alia, by eliminating currency risk.

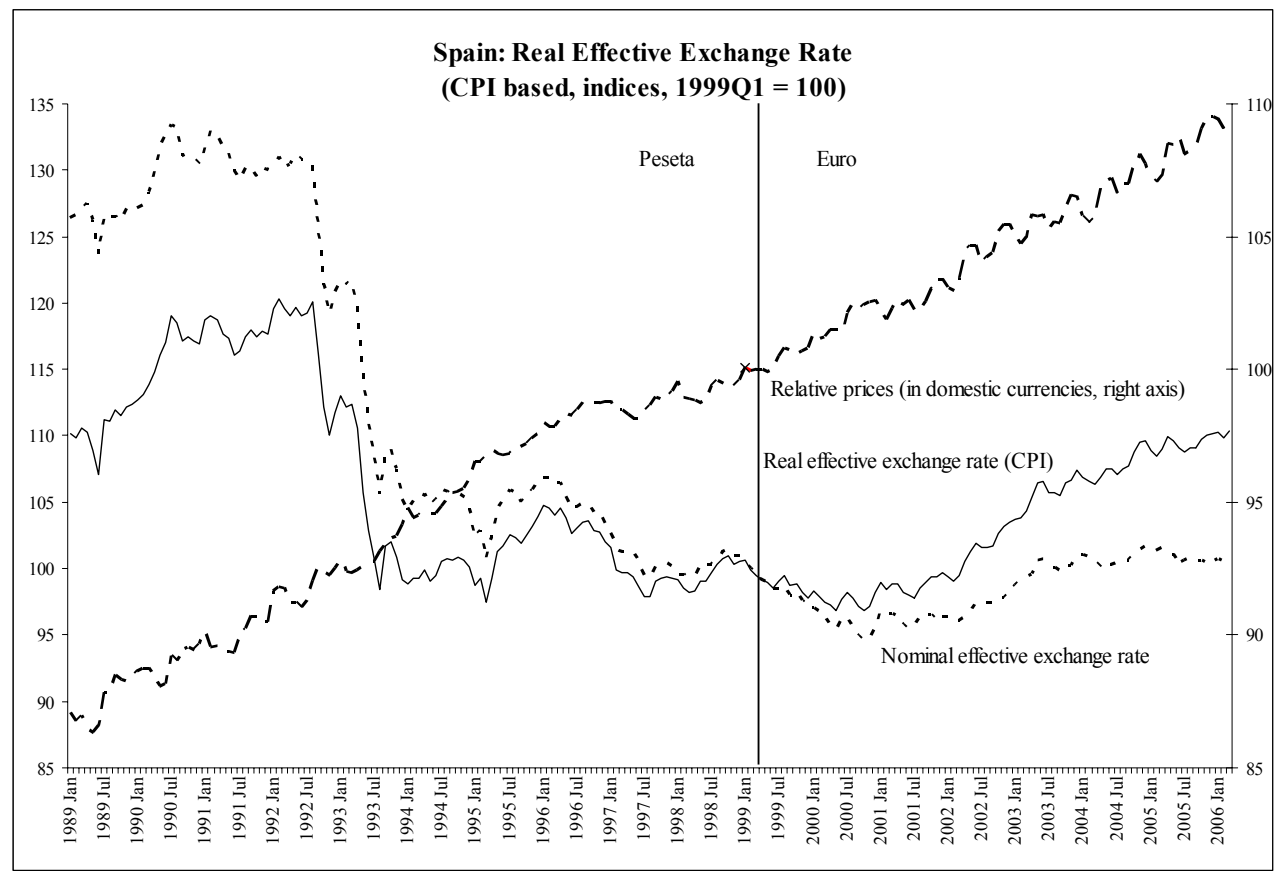

12. Staff agreed, but noted that, by the same token, in the absence of sufficiently flexible product and labor markets, regaining competitiveness could entail a long and difficult process weighing on output and employment - as evidenced by some other euro area experiences. ${ }^{2}$ In this context, the main downside risks remain real estate overvaluation

\footnotetext{
${ }^{2}$ In this regard, the authorities forcefully felt that comparisons to either Italy or Portugal were strained and misplaced, overlooking important differences between these realities (most notably the fiscal and growth performances of recent years). Staff concurred, but noted that, mutatis mutandis, these experiences still epitomized the difficulties of correcting accumulated imbalances and competitiveness weaknesses in a monetary union.
} 


\section{Box 2. Spain's Competitiveness: What is the Evidence?}

The current account position has deteriorated from an average deficit of close to $2 \frac{1}{2}$ percent of GDP since EU accession in 1986 to one of 71/2 percent of GDP in 2005 (Panel A). This reflects primarily a widening trade deficit, but the income and current transfer balances have also deteriorated owing to larger interest payments (as net international liabilities increased), migrant remittances, and lower EU transfers. The trade deterioration, in turn, reflects the cyclical position and oil prices, but also structural competitiveness problems. In staff's view, a range of evidence points in this direction.

Staff estimates based on a decomposition of the current account balance for the 1980-2005 period indicate that oil prices explain about 33 percent of its variation, with the cyclical position accounting for an additional 37 percent. The remaining unexplained residual, about 30 percent, has become increasingly negative (particularly since 2003) and amounted to $2 \frac{1}{2}$ percentage points of GDP in 2005, presumably reflecting in part underlying competitiveness losses (as well as, in part, the impact of weaker demand in Spain's traditional export markets). These estimates are consistent with those of private sector analysts, discussed during the mission. A staff cross-country study ${ }^{3}$ showed that conjunctural variables have recently underestimated Spain's trade deficit, also pointing to emerging structural factors. As noted in the main text, the authorities are of the view that part of the deficit could simply reflect an intertemporal saving-investment decision, whose resolution need not entail high real sector costs, and pointed also to the importance of EMU membership in mitigating risks associated with current account deficits. They also noted an encouraging pickup in recent export growth as possibly indicating a turning point in the external sector's contribution.

Spain's trade-weighted export market share increased until about 1998. Since then, it has stagnated, declining as from 2003 (Panel B). Import volume penetration has risen continuously (Panel C) - with the worldwide decline in import deflators causing a temporary recovery in nominal terms during 200103. Reflecting both lower productivity and higher labor cost growth, the manufacturing unit labor cost differential with the euro area has widened by 16 percentage points since 1995 (Panel D). As a consequence, indicators of Spain's export margins have exhibited the weakest evolution among other large euro-area economies since 1995, albeit recovering somewhat since 2003 (Panel E). The authorities agreed that these data, though susceptible to nuanced interpretations, tend to point to the presence of a component of loss of competitiveness in explaining the current account deficit, whose extent is however difficult to determine precisely.

Real exchange rate developments also show an erosion of competitiveness (Panel F). Given the theoretical and practical difficulties associated with estimating equilibrium real exchange rates, the staff employed several methodologies to assess, in a broadly illustrative manner, the improvement in competitiveness (as measured by the real effective exchange rate) required to (a) satisfy long-term equilibrium determinants drawn from cross-country panel data analyses (net foreign assets relative to exports, commodity prices, labor productivity and production in the manufacturing sector), along the lines of the Fund's macroeconomic balance approach; (b) achieve the trade deficit that would stabilize net external liabilities close to their current level; and (c) achieve the average trade deficit of the last 20 years. Though such methodologies have known shortcomings, with the results contingent on the

\footnotetext{
${ }^{3}$ Allard et. al. (2005): "France, Germany, Italy, and Spain: Explaining Differences in External Sector Performance Among Large Euro Area Countries", IMF Country Report No. 05/401.
} 


\section{Box 2. Spain's Competitiveness: What is the Evidence? (concluded)}

assumptions and subject to large estimation errors, they all suggest appreciable competitiveness weakness (in a range of 23-30 percent). This magnitude needs however to be interpreted with considerable caution. Indeed, the authorities strongly feel that the lack of consensus around the theoretical models on which to base specifications, and the high degree of discretion in setting out the hypotheses that condition the estimation outcomes, detract considerably from the significance of such calculations. Furthermore, the analysis assumes that the current account adjustment would take place exclusively through real exchange rate depreciation. However, they note, the adjustment could also come from a gradual increase in savings.
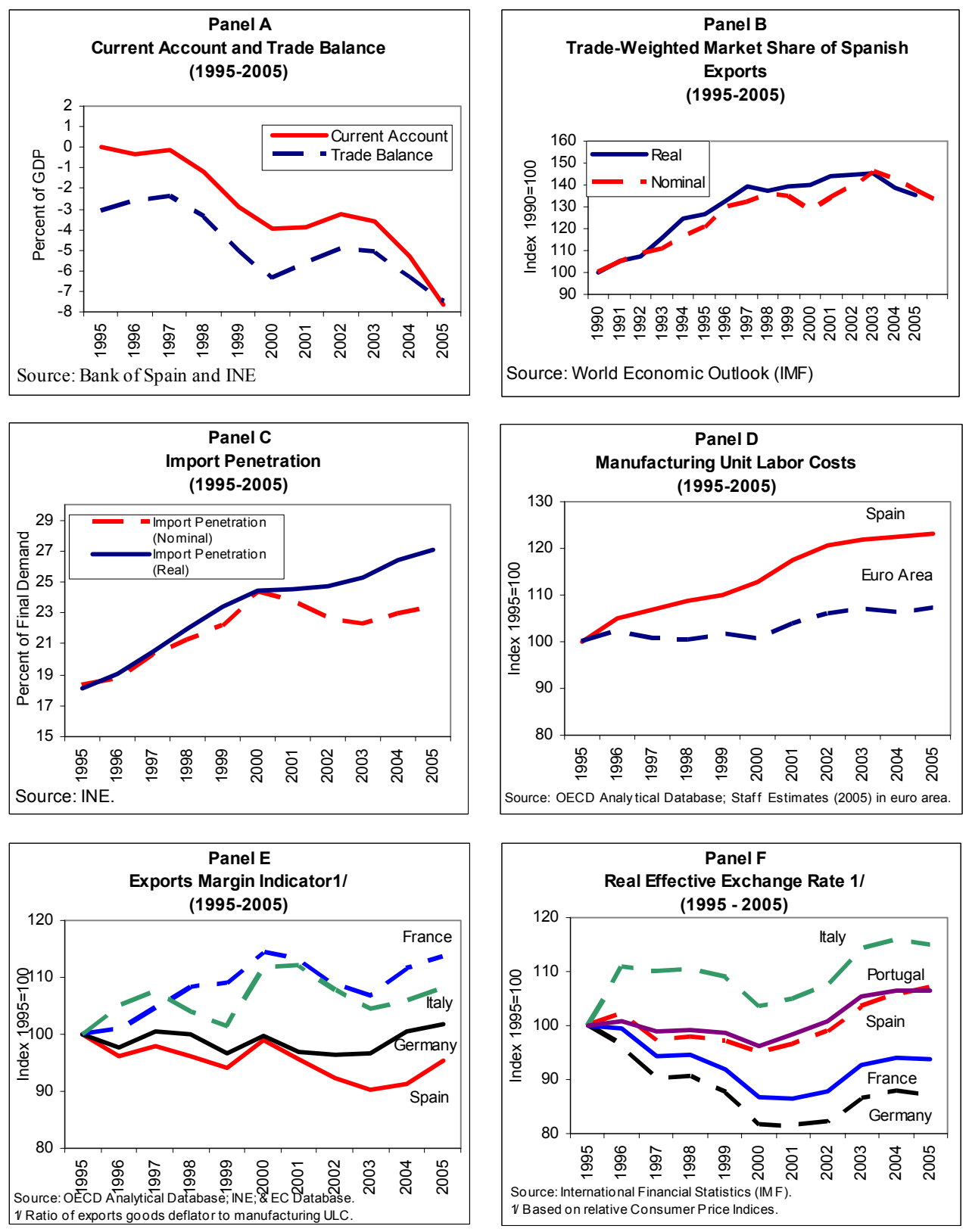
and associated household indebtedness. A demand retrenchment accompanied by a downward house price adjustment would negatively affect the construction sector, which accounts for $10 \frac{1}{2}$ percent of output and 14 percent of employment. On the positive side, FSAP and Bank of Spain analyses indicate that the financial system is well-positioned to withstand shocks of a plausible magnitude - including a hypothetical fall in real house prices of slightly over 17 percent in the first year and of $4 \frac{1}{2}$ percent in the subsequent year, ${ }^{4}$ a 30 percent drop in equity prices, or an abrupt depreciation of the US dollar. Nonetheless, staff remained more concerned than the authorities about the risks attendant to the current situation, and consequently argued for a more vigorous structural and countercyclical policy response. There was agreement that the solution to the productivity and related competitiveness problem lies first and foremost in structural reforms. Staff noted that these however take time, during which fiscal policy should be directed to attenuating imbalances.

\section{B. Dampening Demand-The Task of Fiscal Policy}

\section{Buoyant tax collections resulted in an appreciable budget surplus in 2005 , but the fiscal stance was only mildly restrictive, if at all, owing to an expansion in outlays.} The achievement of a fiscal surplus (1.1 percent of GDP) and further reduction in public liabilities are the result of the authorities' successful efforts over several years to shore up support for sound public finances - a support the mission found in all of its encounters, including with the trade unions. While welcoming this achievement, staff argued that, from a cyclical standpoint, the fiscal stance in 2005 had been inadequate owing to excessive growth in public spending. Conventional cyclically adjusted balance estimates indicate a fiscal withdrawal of about a $1 / 4$ percentage point of GDP. But beyond this indicator and its related measurement difficulties, the staff's analysis (and work by the Bank of Spain) indicate that public spending increases have a significantly larger expansionary impact on demand and the current account than the contractive impact of

\begin{tabular}{|c|c|c|c|c|c|c|}
\hline \multicolumn{7}{|c|}{$\begin{array}{l}\text { Spain: Summary Fiscal Indicators } \\
\text { (In percent of GDP) }\end{array}$} \\
\hline & Revenue & Expenditure & $\begin{array}{c}\text { Fiscal } \\
\text { Balance }\end{array}$ & \multicolumn{2}{|c|}{$\begin{array}{c}\text { Structural } \\
\text { Balance } 1 /\end{array}$} & Debt \\
\hline 2003 & 38.3 & 38.3 & 0.0 & \multicolumn{2}{|r|}{0.1} & 48.9 \\
\hline 2004 & 38.7 & 38.8 & -0.1 & \multicolumn{2}{|r|}{0.8} & 46.4 \\
\hline 2005 & 39.3 & 38.2 & 1.1 & \multicolumn{2}{|r|}{1.1} & 43.2 \\
\hline $20062 /$ & 39.3 & 38.4 & 0.9 & \multicolumn{2}{|r|}{0.9} & 39.4 \\
\hline $20072 /$ & 39.1 & 38.4 & 0.7 & \multicolumn{2}{|r|}{0.7} & 36.3 \\
\hline Average 2008-10 2/ & 38.8 & 38.3 & 0.4 & \multicolumn{2}{|r|}{0.4} & 31.3 \\
\hline \multicolumn{7}{|c|}{$\begin{array}{l}\text { 1/ The balance for } 2004 \text { excludes one-time spending of } 0.7 \text { percent of GDP. } \\
\text { 2/ Projection. }\end{array}$} \\
\hline \multicolumn{7}{|c|}{$\begin{array}{c}\text { Fiscal Developments 2004-05 } \\
\text { (Percentage of GDP) }\end{array}$} \\
\hline & & \multicolumn{2}{|c|}{2004} & 2005 & Change & $\begin{array}{c}\text { Nominal } \\
\text { Growth } \\
\text { (percent) }\end{array}$ \\
\hline \multicolumn{7}{|c|}{ General Government } \\
\hline \multicolumn{3}{|c|}{ Revenue } & 38.7 & 39.3 & 0.6 & 9.8 \\
\hline \multirow{2}{*}{\multicolumn{3}{|c|}{$\begin{array}{l}\text { Adjusted primary expenditures } 1 / \\
\text { Interest Payments }\end{array}$}} & 36.1 & 36.4 & 0.3 & 9.0 \\
\hline & & & 2.1 & 1.8 & -0.2 & -7.4 \\
\hline \multicolumn{7}{|c|}{ Central Government } \\
\hline \multicolumn{3}{|l|}{ Revenue } & 14.1 & 14.6 & 0.5 & 11.8 \\
\hline \multicolumn{3}{|c|}{ Adjusted Expenditure 1/ 2/ } & 14.2 & 14.2 & 0.0 & 7.8 \\
\hline \multicolumn{7}{|l|}{ Social Security } \\
\hline \multicolumn{3}{|l|}{ Revenue } & 12.6 & 12.6 & 0.0 & 8.0 \\
\hline Expenditure & & & 11.6 & 11.5 & -0.1 & 7.1 \\
\hline Territorial Goverı & ments & & & & & \\
\hline Adjusted Revenu & & & 19.9 & 20.2 & 0.3 & 9.6 \\
\hline Expenditure & & & 20.2 & 20.6 & 0.4 & 10.1 \\
\hline
\end{tabular}

\footnotetext{
${ }^{4}$ Part of an FSAP stress test scenario considering a 30 percent fall in real house prices spread over five years, in line with the profile observed in the early 1990s.
} 
equivalent revenue gains (Box 3). ${ }^{5}$ In this light, staff argued, the effective fiscal stance was expansionary in 2005, with general government non-interest spending rising by 0.3 percentage points of GDP (adjusted for one-time balance-sheet operations recorded in 2004).

14. The authorities were confident that another appreciable fiscal surplus was in the offing, laying the basis for a strong performance in $\mathbf{2 0 0 7}$ as well. With 2006 revenues set to exceed budget projections by a wide margin (partly due to the regularization of immigrants), the authorities intended to allow the full play of automatic stabilizers, and expected another significant general government surplus, possibly above the 0.9 percent of GDP projected in the updated Stability Program. Staff, while sharing this expectation, noted that budget spending plans again implied an expansionary stance, with real expenditure outpacing real GDP

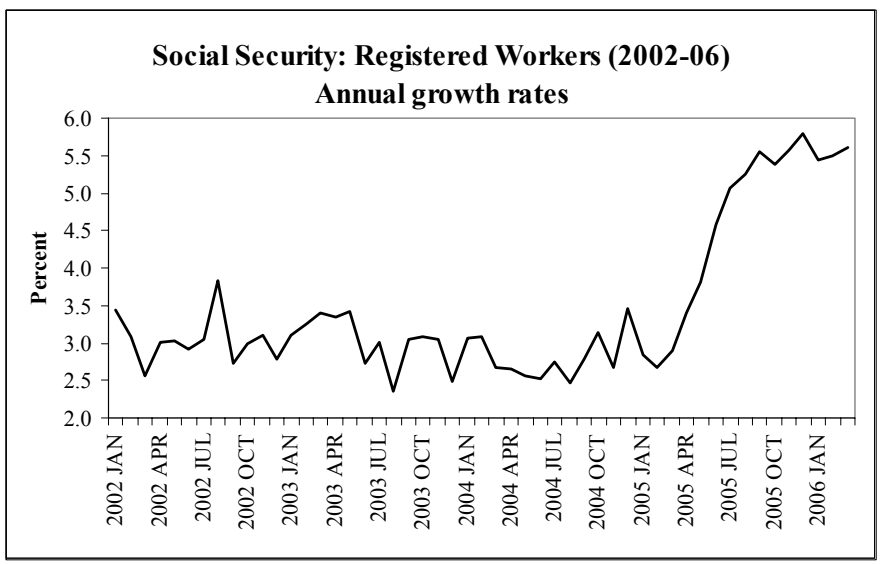
growth: for example, central government consumption was budgeted to rise in real terms by 4.1 percent in 2006 .

15. Staff advocated greater expenditure-based fiscal restraint. Specifically, staff saw merit in directing fiscal policy toward the goal of improving the 2006 general government surplus by at least $1 / 2$ percentage point of GDP (relative to 2005), based on expenditure control, to contain demand pressures. To this end, the central government should aim to keep spending appreciably below current ceilings and safeguard the budget's contingency fund for truly exceptional events. For their part, the regions should move to balance in 2006 and surplus by 2007 - consistent with the new Budget Stability Law due to take effect that year.

16. The authorities saw only limited scope for reining in already budgeted spending. While not disputing the expansionary impact of public spending, and sharing concerns about its dynamics at the regional and local level, the authorities emphasized that the central government had remained within its expenditure ceiling in 2005 and would continue to do so. They did not however see scope for significant underspending, and pointed to the political economy difficulties of explicitly aiming for rising fiscal surpluses, a prospect that

\footnotetext{
${ }^{5}$ See accompanying Special Issues paper and Bank of Spain, Boletín Económico, March 2006.
} 


\section{Box 3. Fiscal Policy: Can it Help Attenuate Imbalances?}

While only structural policies can improve competitiveness and growth on a lasting basis within EMU, the question arises of whether fiscal policy could contribute to attenuating imbalances in the short term, as reforms take hold. Staff has analyzed the effects of fiscal policy - using a structural vector autoregression model - with a particular focus on the current account and the (manufacturing ULCbased) real exchange rate. The results, set out in a Selected Issues paper, indicate that:

- $\quad$ A 1 percent exogenous fall in real government expenditure in one quarter-which persists over one year-improves the current account balance by about $0.15-0.16$ percentage points of GDP for one year and prompts a $0.4-0.6$ percent depreciation in the real exchange rate by moderating ULC growth. The effects of the shock decline slowly after two years.

In contrast, the effects of a tax revenue shock appear statistically insignificant. This statistical result partially reflects the fact that, during the sample period, tax revenue increases tended to be followed shortly thereafter by spending increases which offset the dampening effect of higher taxes. The result is also broadly consistent with Ricardian equivalence, in which tax policy changes are countered by private agents' forward-looking consumption-saving decisions, of which there is also some partial evidence.
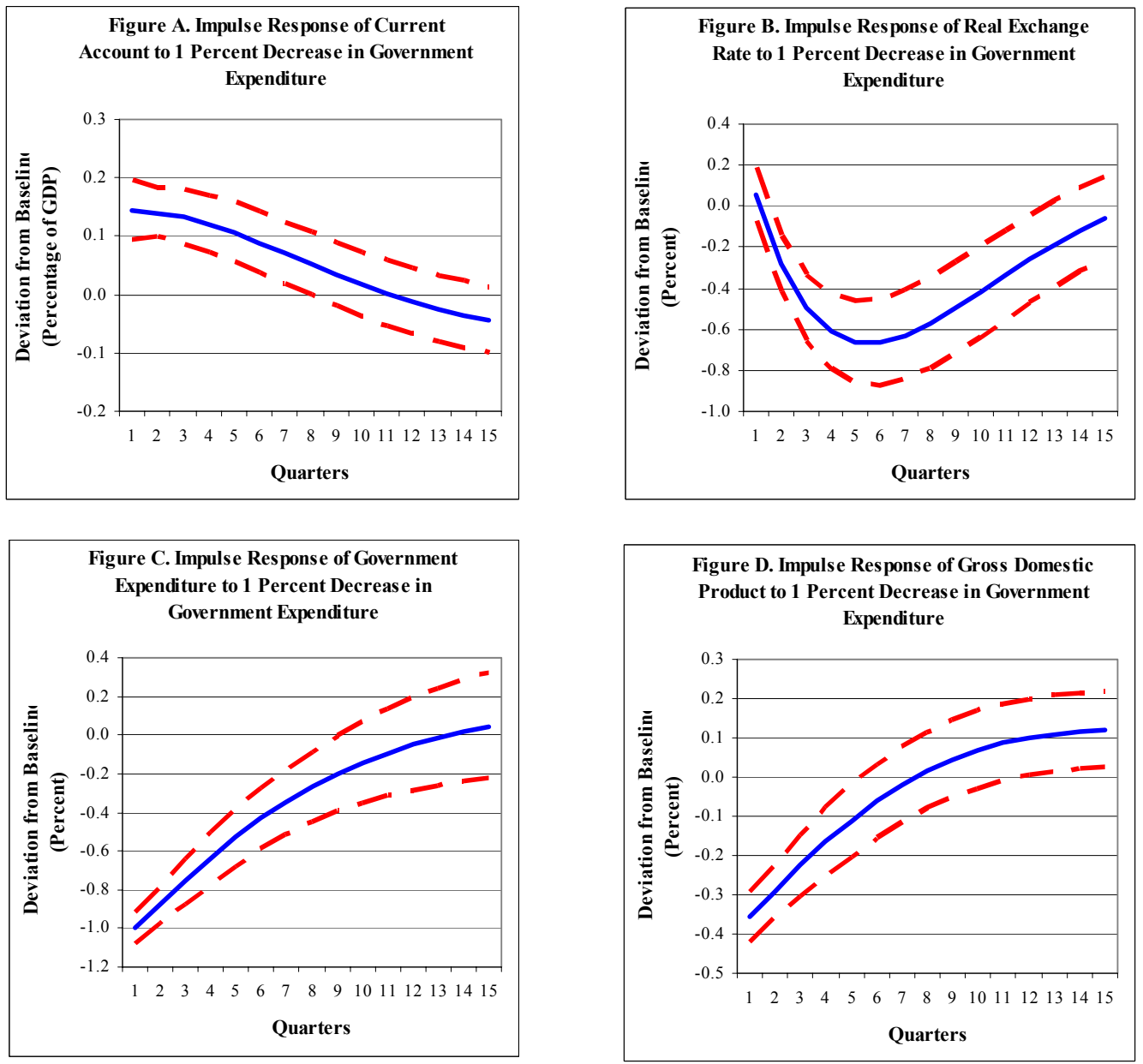
would whet spending appetites. ${ }^{6}$ The exceptional wave of immigration into Spain was furthermore seen to generate its own, warranted expenditure needs with regard, for example, to infrastructure, social services, education, and the judiciary. Furthermore, the government's emphasis on improving productivity and raising R\&D spending also entailed a public effort.

\section{Maintaining Fiscal Stability in the Medium and Long Term}

\section{A new Budget Stability Law (BSL), introducing greater cyclical flexibility and} aiming to increase ownership and observance by the regions, is currently before Parliament. It is expected to take effect in 2007. The draft BSL (Box 4) seeks to allow the operation of automatic fiscal stabilizers by making budget targets contingent on the cyclical position, while aiming for fiscal balance over the cycle - an approach consistent with past Fund advice. Staff welcomed other positive features of the draft law. First, the new "balance over-the-cycle" target will apply to the general government with exclusion of the social security system (currently running a 1 percent of GDP surplus). In this respect, the authorities noted that it is more stringent than SGP requirements. Second, the draft law bars state bail-outs for lower government levels, a feature judged to be essential in the absence of legally binding enforcement mechanisms. Third, the new framework envisages strengthened reporting requirements to increase fiscal transparency of territorial governments, seen by all as an essential counterpart to the increased flexibility granted by the new law. While welcoming progress on this front, staff still judged the information flow to be insufficient to allow early identification of profligate fiscal behavior, elicit public censure, and stimulate corrective action.

\section{The mission pointed to several features of the draft law that, in providing} appreciable leeway, risked rendering "balance over-the-cycle" an elusive target. ${ }^{7}$ Staff noted three main concerns: first, the asymmetry in specifying a deficit limit in the case of low growth but not a commensurate surplus requirement in the high-growth scenario, entailing a risk of insufficiently ambitious targets in good times - such as the present. The authorities agreed that much would depend on implementation but saw drawbacks in setting a minimum surplus target for the high-growth scenario (it could become a ceiling). Second, the exclusion of part of capital spending was, in staff's view, insufficiently precise. The increasing

\footnotetext{
${ }^{6}$ After the mission, the authorities announced the intention to contain central government spending growth in 2007 to that of nominal GDP, and an agreement on targets for territorial governments (a deficit of 0.2 percent of GDP in 2007 and balance thereafter). While both policy objectives improve upon 2005-06, staff views them as insufficiently ambitious.

${ }^{7}$ At last year's consultation, staff and many Directors "advised that the regions should consistently aim at budget balance, avoiding a build-up in subnational debt." In contrast, the new BSL would, in a low-growth scenario, allow territorial governments to incur a deficit of up to 1.1 percent of GDP.
} 


\section{Box 4. The New Budget Stability Law}

Fiscal targets. The proposal targets a fiscal balance over the cycle for the general government, excluding the social security system. To avoid the complexities of defining the cyclical position, it establishes targets for three states of the economy: a fiscal balance for normal growth (set at between 2 and 3 percent for the 2007-09 period); a small public deficit for low growth; and a surplus (of underdetermined size) for high growth. For the social security system, it envisages a separate target, set to ensure its financial sustainability.

Allocation of the targets. The low-growth deficit (up to 1 percent of GDP) is allocated predominantly ( 0.75 percent of GDP) at the regional government level. No indication is provided, however, about the level and allocation of the high-growth surplus.

Individual targets. Targets for each region will be determined by bilateral negotiations. If these are inconsistent with the overall target, the Ministry of Economy can set individual targets.

Excluded capital expenditure. The proposed law excludes capital (and some other) expenditure aimed at improving productivity and competitiveness, in an amount up to 0.5 percent of GDP, of which half is allocated to the regions. Thus, the total low-growth deficit for the central and territorial governments is 1.5 percent of GDP.

Enforcement. Three-year corrective plans are envisaged for any level of government that fails to reach the balance over-the-cycle target. Enforcement relies on expected increased transparency and timeliness of subnational data, and on an explicit barring of regional government bail-outs.

\begin{tabular}{|c|c|c|c|c|}
\hline & $\begin{array}{c}\text { Level of } \\
\text { Government }\end{array}$ & $\begin{array}{c}\text { Target } \\
(\mathrm{T}-\mathrm{G}+\text { Cap*) } \\
\end{array}$ & $\begin{array}{c}\text { Excluded capital expenditure } \\
(\text { Cap*) }\end{array}$ & $\begin{array}{c}\text { Fiscal balance } \\
\text { (T-G) }\end{array}$ \\
\hline \multicolumn{5}{|l|}{ State of the economy: } \\
\hline $\begin{array}{l}\text { Normal growth } \\
\text { (between } 2 \text { and } 3 \text { percent) }\end{array}$ & $\begin{array}{l}\text { Central } \\
\text { Regional } \\
\text { Local }\end{array}$ & $\begin{array}{l}\text { Balance } \\
\text { Balance } \\
\text { Balance }\end{array}$ & $\begin{array}{c}0.20 \text { percent of GDP } \\
0.25 \text { percent of GDP } \\
0.05 \text { percent of GDP }\end{array}$ & $\begin{array}{l}-0.20 \text { percent of GDP } \\
-0.25 \text { percent of GDP } \\
-0.05 \text { percent of GDP }\end{array}$ \\
\hline $\begin{array}{l}\text { Low growth } \\
\text { (less than } 2 \text { percent) }\end{array}$ & $\begin{array}{l}\text { Central } \\
\text { Regional } \\
\text { Local }\end{array}$ & $\begin{array}{l}-0.20 \\
-0.75 \\
-0.05\end{array}$ & $\begin{array}{l}0.20 \text { percent of GDP } \\
0.25 \text { percent of GDP } \\
0.05 \text { percent of GDP }\end{array}$ & $\begin{array}{l}-0.4 \text { percent of GDP } \\
-1.0 \text { percent of GDP } \\
-0.1 \text { percent of GDP }\end{array}$ \\
\hline $\begin{array}{l}\text { High growth } \\
\text { (greater than } 3 \text { percent) }\end{array}$ & $\begin{array}{l}\text { Central } \\
\text { Regional } \\
\text { Local }\end{array}$ & $\begin{array}{l}\text { Surplus } \\
\text { Surplus } \\
\text { Surplus }\end{array}$ & $\begin{array}{l}0.20 \text { percent of GDP } \\
0.25 \text { percent of GDP } \\
0.05 \text { percent of GDP }\end{array}$ & $\begin{array}{l}\text { Surplus - } 0.20 \text { percent of GDP } \\
\text { Surplus }-0.25 \text { percent of GDP } \\
\text { Surplus - } 0.05 \text { percent of GDP }\end{array}$ \\
\hline
\end{tabular}

1/ The proposal excludes the social security system, which is envisaged to be in balance in the long-run. It also proposes to calculate percentages in terms of the relevant GDP, i.e., national (regional) GDP for the central (regional) government.

recourse to off-budget capital spending by regional and municipal governments was, in this regard, already a concern. The authorities felt that exclusion of certain spending reflected the high priority assigned to improving Spain's lackluster productivity performance, and that circumvention would in any event be contained by the overall cap on such spending. Finally, staff noted that the draft BSL did not clearly specify whether, in good times, the surplus requirement would apply to the Autonomous Communities as a whole, or to each individual Community. This ambiguity could give rise to conflicting interpretations, which were evident during the mission's discussions, and consequent implementation difficulties. The authorities recognized the ambiguity but viewed it as constructive, providing scope to address the main challenge to any fiscal framework in Spain: the need to coordinate the 
highly decentralized regional and municipal budgets, which encompass over 70 percent of public expenditure excluding social security.

19. In sum, the authorities viewed the new fiscal framework as promoting coresponsibility in a manner that would maintain fiscal discipline while respecting the constitutional autonomy of the regions. They noted that the framework provided for an articulated system of annual negotiations, agreements, and monitoring among the central and regional governments that would ensure a greater degree of buy-in than currently prevailing. They agreed that transparency and accountability were ultimately the main enforcement mechanisms available, and intended to give priority to strengthening the role of the entities charged with ensuring these (the State Administration's General Audit Office, IGAE, and the regional coordinating council, Consejo de Politica Fiscal y Financiera). They were inclined to leave for later consideration, while not discarding, the possibility of seeking means to obtain an independent assessment of fiscal policies of the various levels of government and of their consistency with the BSL. They also noted the recent progress in implementing some recommendations of the 2005 fiscal ROSC.

20. In parallel with the new BSL, territorial financing arrangements are also under review. A recently agreed reform of the Statute of Autonomy for Catalonia contains changes to financing arrangements, which could act as a broad blueprint for a more general reform of territorial financing. The Catalonian arrangements foresee the transfer of a higher share of taxes from the central government, alongside some greater taxing autonomy. Staff argued that the latter needed to be the key feature of the new system: a successful decentralization of competencies had to be accompanied by mechanisms that granted territorial governments significant powers to set their own taxes. The authorities agreed and indicated that the new arrangements would do so-particularly with respect to the personal income tax. They also viewed with favor forms of regional sales tax, but issues of compatibility with EU rules would need to be addressed. In contrast, they felt strongly that the corporate income tax should remain uniform throughout the nation, so as to avoid undue tax competition. Staff noted, however, that unless central government transfers were cut back, the current institutional framework provided little incentive for regional and municipal governments to use their enhanced tax powers - as evident from experience to date.

\section{Healthcare provision also has an important financing dimension, currently} under review-providing an opportunity for broader healthcare reform. Public spending on healthcare (a decentralized competency) has reached 6 percent of GDP and is growing rapidly. Given regional governments' spending overruns in this area, healthcarerelated transfers from the central government had to be increased by 0.2 percent of GDP over budgeted levels in 2005, and health appropriations raised in 2006, until a new cost-sharing arrangement between levels of government is established in 2007. The authorities expect that the new financing arrangements will provide incentives for regional budgets to contain costs and are introducing stricter controls and rationalizing procurement. Staff argued the need for a broader reform of the system, with effective cost containment likely to require forms of private participation and cost-sharing, such as user co-payments to rationalize demand. 
Similarly, it cautioned that commitments under a new disability law (Ley de Dependencia) be costed carefully and its beneficiaries targeted closely, so as to avoid another potential source of spending pressure.

\section{The authorities recently unveiled a limited tax reform, aimed at simplifying the} tax system and reducing distortions in the taxation of savings. They explained the deliberate caution exercised in reducing the tax burden as being based on concerns about the impact on current demand pressures - though, staff noted, such concerns could have been eased, and the tax reduction been larger, if accompanied by greater spending restraint. The reform - to enter into effect in 2007-reduces the marginal personal income tax rate and the number of brackets, introduces a uniform rate on savings (18 percent), and foresees a phasedin reduction of the corporate tax rate by 5 percentage points, while eliminating a range of tax deductions. Employers, however, considered the rate cut insufficient and more than offset by the elimination of deductions, a view disputed by the authorities, especially for small- and medium-sized enterprises. A generally shared positive feature of the reform is the uniform tax on savings, which was seen to enhance competition among financial instruments. There was however some concern that the reduction in tax-exempt contributions to private pension plans_-which are still small and need encouragement—-may send a deterring signal and heighten uncertainty about their future tax treatment. Finally, the reform did not eliminate the mortgage deduction - a long-standing staff recommendation.

\section{From a longer-term perspective, the fiscal outlook is clouded by the lack of progress in the reform of pension and other age-related costs. Long-term fiscal} projections prepared by the authorities and the EC's Aging Working Group place Spain among the EU countries with the largest age-related spending increase over the next 25-50 years - this despite upward revisions in population growth reflecting current immigration trends and rather sanguine assumptions on future labor utilization and productivity. Apart from some initial reforms in 1997, the authorities have so far limited the policy response to the accumulation of social security surpluses in a special reserve fund, which has reached $3 \frac{1}{2}$ percent of GDP, allowing the postponement of funding shortfalls by five years. Nevertheless, the authorities agree that a definitive solution will require a

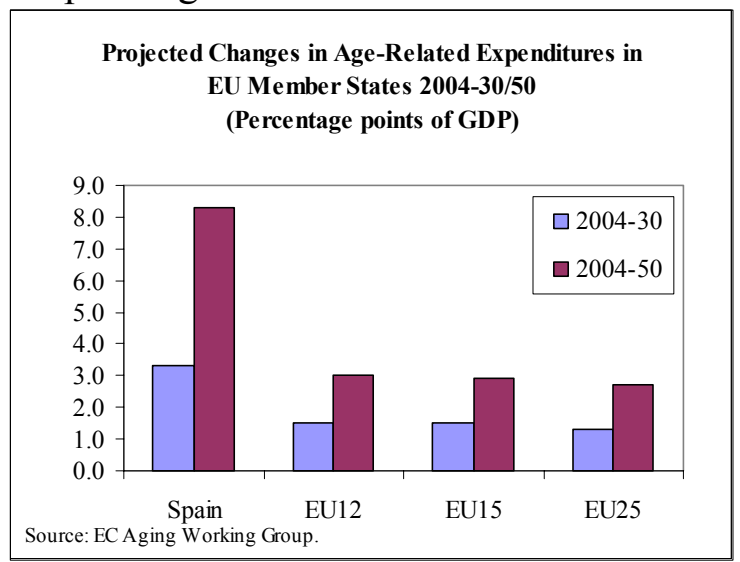
reform of entitlements, but prolonged discussions with social partners have yet to come to closure. At the time of the mission, the focus was mainly on reducing early retirement schemes and, possibly, raising the minimum contribution period by a marginal amount. With social security deficits expected to arise within the next decade, staff noted that reform initiatives would need to be timely and more broad-ranging, encompassing actuarially fair incentives to prolong the effective working life, an extension of the base period to compute pensions, and a further expansion of private provision. 


\section{Creating a More Competitive Spain_-Product and Labor Market Reforms}

24. The authorities have formulated an ambitious and detailed reform agenda to improve the dynamism of the economy. It encompasses the Dynamization Plan (February 2005, updated March 2006) and the National Reform Program (NRP, October 2005), which aim at increasing productivity and the employment rate. In the authorities' analysis, per capita GDP growth has been driven in recent years by rising employment rates stemming from the incorporation into the labor force of large immigration flows and rising female participation. As these inflows wane, however, further advances in GDP per capita will require faster labor productivity growth, which is among the lowest in the OECD (Box 5). Regarding specific measures, the NRP emphasizes the government provision of public goods (infrastructure, education) and government sponsorship of activities with positive externalities (R\&D, start-up companies). It places comparatively less weight, however, on enhancing competition-based incentives to the efficient allocation of resources, cost reduction, and innovation.

\section{Staff agreed with the authorities' analysis while emphasizing the central role} that fostering competition and deregulating sheltered sectors would need to play in regaining competitiveness. ${ }^{8}$ These sectors are the major contributors to the widening price and cost differential with trading partners. An insufficient degree of competition and the associated pricing power-as shown by the differential evolution of markups between tradables and nontradables — are major factors behind the persistent competitiveness losses. ${ }^{9}$ Indeed, Spain has not experienced the productivity gains in distribution and services that have been the hallmark of economies where productivity accelerated in the last decade. Most observers and the mission's interlocutors attributed the sluggish performance of the services sector to the lack of contestable markets and incentives to innovate. ${ }^{10}$

\footnotetext{
${ }^{8}$ The authorities' decomposition of the OECD's index of product market regulation indicates that Spain compares favorably on barriers to external trade and foreign investment. Its low overall raking $\left(19^{\text {th }}\right.$ out of 29$)$ stems from low scores on impediments to entrepreneurship, administrative barriers, and government presence in domestic markets.

${ }^{9}$ For the effect of lack of competition on the inflation differential, see ECFIN Country Focus, Vol. 112, July 2004; and Economic Bulletin, Bank of Spain, November 2005. Staff's analyses also indicate significant adverse effects of regional barriers to retail competition (see IMF Country Report 04/89, and Hoffmaister 2006: "Prices and Barriers to Retail Competition: Evidence from Spain," IMF Working Paper, forthcoming).

${ }^{10}$ The literature provides ample evidence that most of the productivity growth in advanced economies stems from the entry and expansion of more productive firms at the expense of the exit and market share losses of the less productive-rather than by productivity improvements within firms. See, inter alia, Foster, Haltiwanger, and Krizan (2001): "Aggregate Productivity Growth: Lessons from Microeconomic Evidence" in New Developments in Productivity Analysis, NBER / University of Chicago Press.
} 

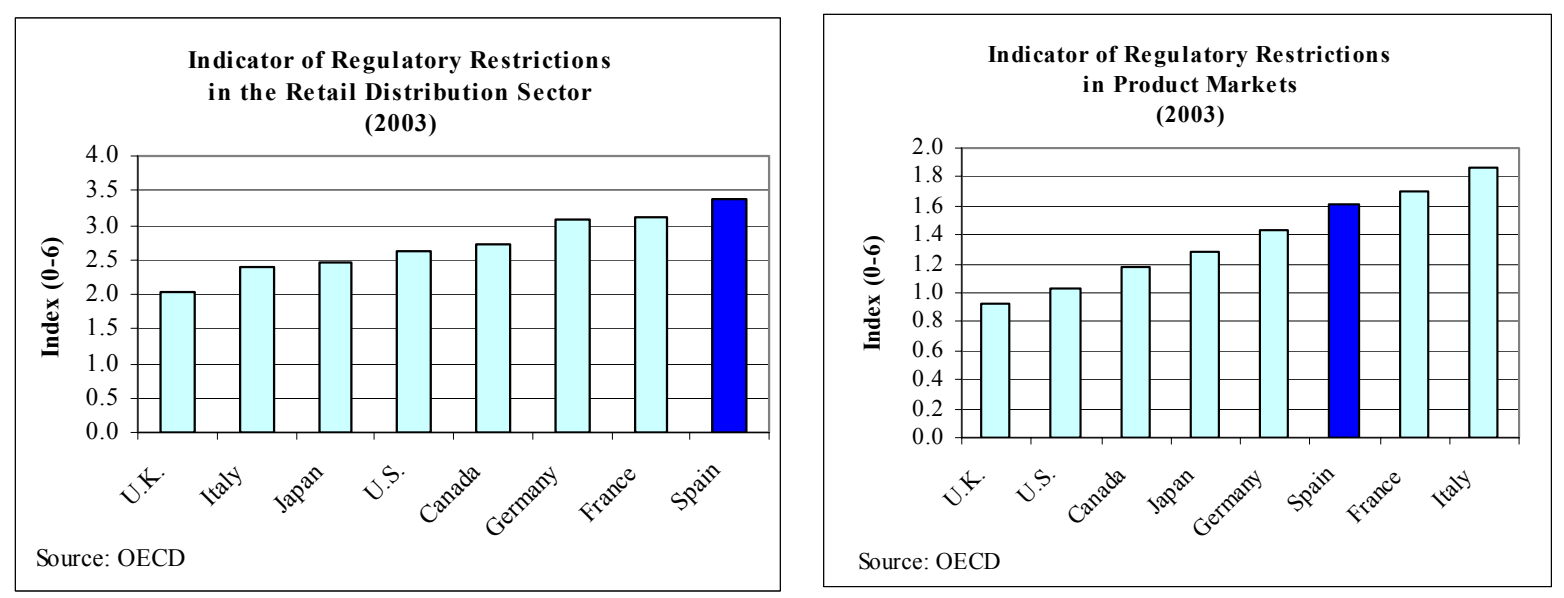

26. Despite a welcome quantification of objectives and close interministerial monitoring of the plans' progress, forward steps in some areas are hindered by political economy factors. Among early positive steps is an ongoing reform of the anti-trust system, designed to consolidate and strengthen the powers of the competition authorities and limit the executive's capacity to overrule its decisions. Also, the authorities have announced a plan to restructure the loss-making public broadcasting company (RTVE). Still, in practice, energy, utilities, telecommunications, transportation, and various professional services remain relatively sheltered from competition. A complex area is that of retail distribution, where responsibilities lie with regional and municipal governments who, with a view to protecting local incumbents, have thwarted the entry of larger, more efficient firms through licensing, zoning, opening time, and other regulations. The authorities were cautiously hopeful that the new EU Services Directive, for which they had supported greater ambition, could offer the opportunity to review existing constraints in this area. In line with their good record in transposing EU Directives, staff encouraged them to exploit this opportunity fully. Less positively, as the EU internal market reaches more sensitive areas - particularly, in the case of Spain, energy, given its import dependence - a "national champions" reaction has arisen. The authorities have eliminated the "golden share" option to block takeovers of privatized public companies. In March 2006 the National Energy Commission (the sectoral regulator) was accorded broad powers over takeovers in the sector. This was widely seen as a move to stymie a foreign bid for a Spanish energy company, which competed with an alternative domestic offer, and the EC has opened an infringement procedure. The authorities observed that the objective of the legislation was to fill a regulatory void concerning takeover bids involving companies which carry on regulated activities, with the main change being an extension of the norm's coverage to the target as well as the bidding company. Staff urged the authorities to refrain from using these newly granted powers in a discriminatory 


\section{Box 5. Productivity: The Trend in Spain is Mainly Plane}

Like other European economies, Spain experienced significant catch-up in labor productivity through the mid-1980s but has since fallen behind. The subsequent slowdown has been more pronounced than in other countries (see table, next page): the productivity gap with respect to a 23 -industrial country sample increased from 9 percent in 1985 to 30 percent in 2004 (or to 23 percent if measured at current prices).

The recent employment expansion is not the main cause of stagnant productivity. Productivity growth underperformance predates the expansion of employment and is not shared by other economies with booming labor markets. Nor can it be ascribed primarily to a low capital stock. When controlling for the capital-labor ratio, residual productivity (total factor productivity) exhibits the same decelerating pattern. (See Selected Issues paper for further details).

Instead, most observers point to the key role of low ICT capital, $R \& D$ spending, and human capital. More deliberate government provision of public goods in these areas could improve productivity performance. Nevertheless, much of the identified deficit lies in the private sector and will require removing obstacles to innovate and invest in new activities. Barriers to competition, restrictive regulations, and labor market rigidities all militate against a more dynamic and entrepreneurial economic environment.

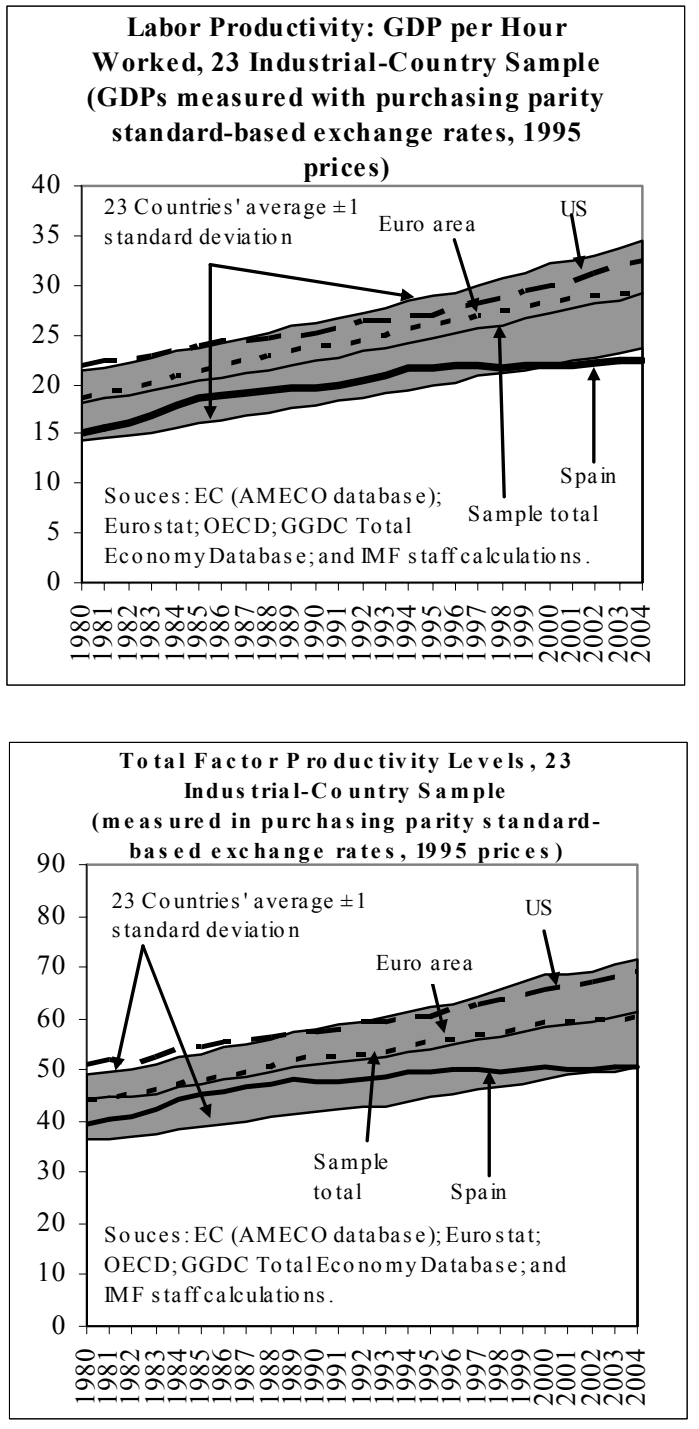


Spain: Sources of Growth. 2001-04 1/

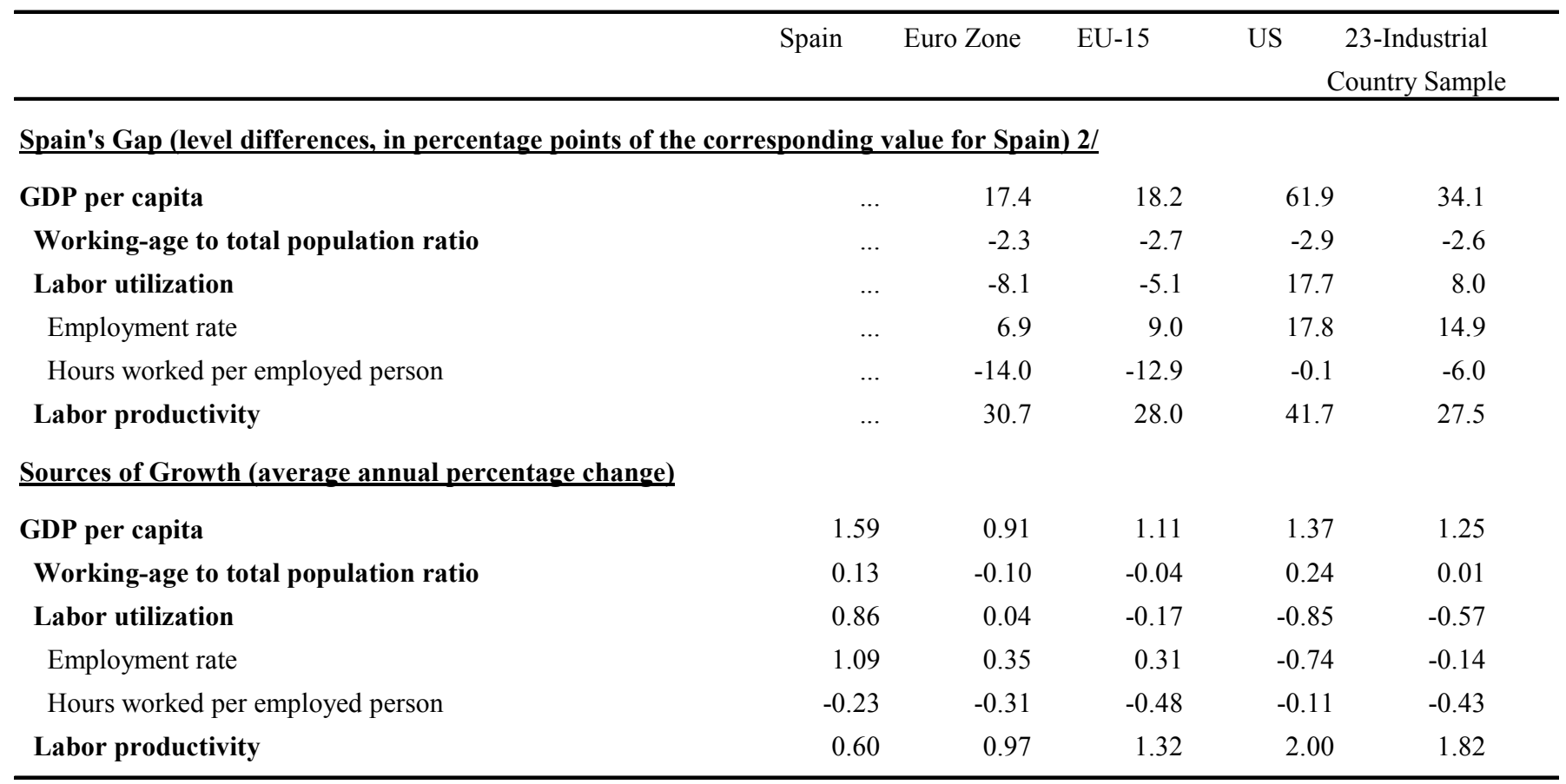

Souces: EC (AMECO database); Eurostat; OECD; GGDC Total Economy Database; and IMF staff calculations.

1/ Indicators for the euro zone, EU-15, and sample totals are for the consolidated group (rather than simple averages for the member countries). "Demographics" is the working-age population to total population ratio; "labor utilization" is hours worked per working-age person; "employment rate" is the ratio of persons employed to working-age population; "labor productivity" is output per hour worked. GDP and capital stock are valued at 1995 prices and converted to a common purchasing parity standard (PPS) unit of account.

2/ Positive numbers indicate a lag of the Spanish economy (Spain $=0$ ) with respect to the reference economy. Conversely, negative numbers indicate that the indicator's value for the Spanish economy is higher than for the reference economy. Components may not add up to totals because (i) they aggregate multiplicatively; and (ii) time averages are computed as the average of the ratios for each period, and thus, the average of the products will not generally agree with the product of the averages. 
manner and to act in close cooperation with the EC on the matter. More generally, staff expressed concerns about the existing appointment procedures to sectoral regulatory agencies, which it did not see as fully guaranteeing their independence.

\section{Although reforms implemented since the last decade are bearing fruit, most} indicators still lag well behind Lisbon objectives and labor markets remain among the most rigid in the OECD. The rising employment rates of female and older workers, large immigration flows, and decline in structural and longterm unemployment are testimony to the growth-enhancing potential of increased labor market flexibility. Prolonged negotiations among social partners focused largely on how to reduce the incidence of temporary labor contracts, which account for 34 percent of total contracts (versus 5-10 percent in most other EU countries). This is possibly due in part to the employment weight of construction, tourism, and agriculture, all highly seasonal activities. However, it is increasingly recognized that the prevalence of temporary contracts mainly reflects the excessive rigidity of regular contracts - even though temporary contracts are also themselves among the most restrictive in the OECD. In addition, staff noted, the collective wage bargaining system is excessively rigid and centralized, preventing labor costs from matching productivity developments, and hindering geographical and sectoral labor mobility.

\section{Agreement on a limited reform to labor contracting was}
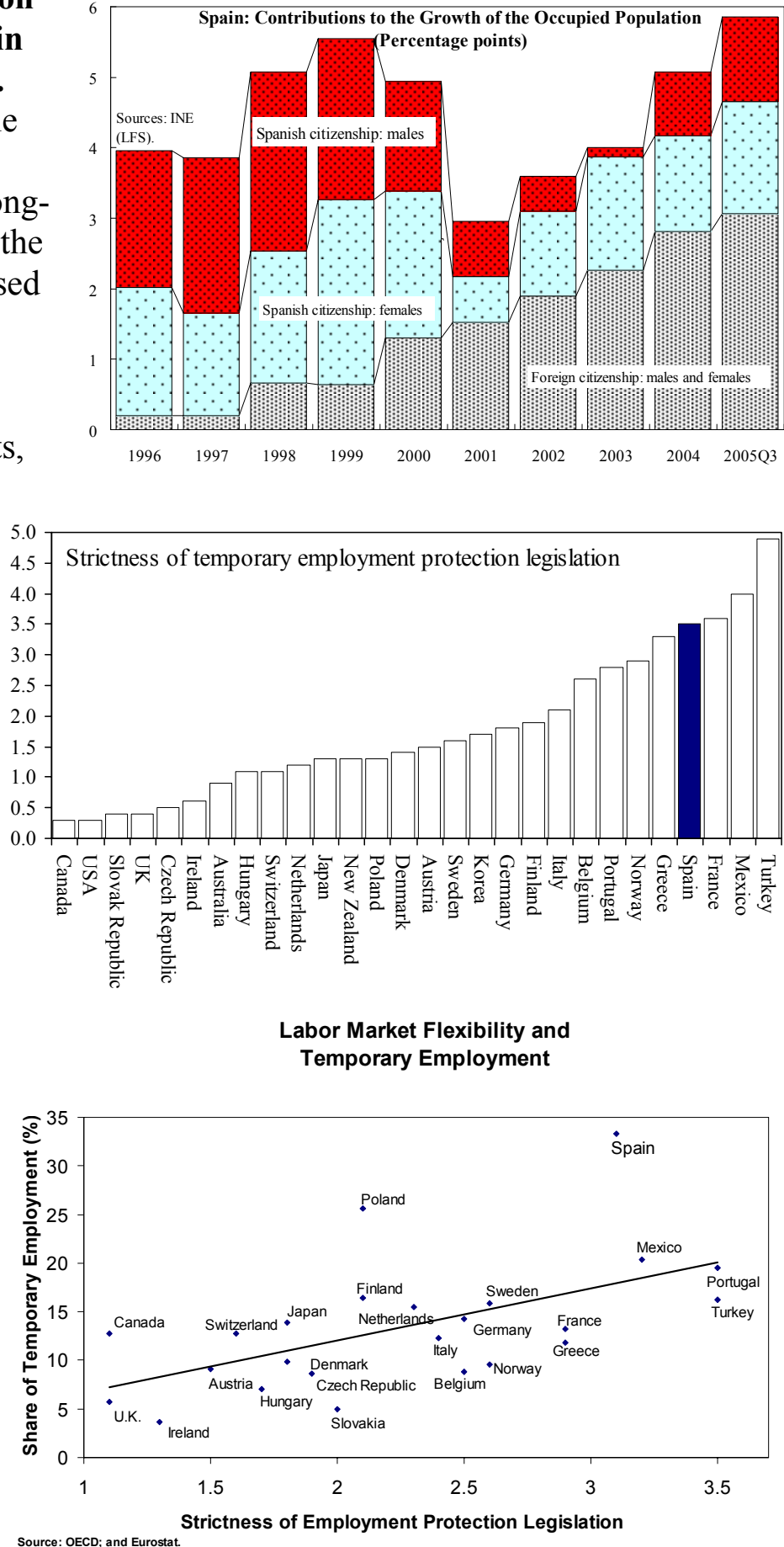
reached in early May. The reform is centered on reducing the incidence of temporary contracts, both via legal provisions and fiscal incentives. A positive feature of the reform is the possibility of applying indefinite contracts with lower firing costs (contratos de fomento, introduced in 1997) to any worker currently on a temporary contract - but only during a limited period (through end-2007). At the same time, it strengthens legal provisions against consecutive temporary contracts, and introduces other limits to their use. Fundamentally, it does not address the key requirement, as seen by staff, of permanently reducing the rigidity and high dismissal costs of regular contracts.

\section{E. Financial Sector}

29. The Financial Sector Assessment Program (FSAP) found a highly dynamic and competitive financial system under strong prudential supervision and regulation (Box 6). The sector's strengths include a high degree of financial intermediation; low intermediation margins; well-capitalized and professionally managed institutions; and a robust and well-developed prudential framework. ${ }^{11}$ Stress tests showed that banks and insurance companies would be able to withstand large adverse shocks without systemic distress. This reflects strong capitalization and risk management practices of systemically important credit institutions, and sizeable loan-loss cushions.

\section{The main risks identified by the FSAP relate to rapid credit growth and to a} potential downturn in the housing market, particularly if combined with an adverse macroeconomic scenario. In this connection, the authorities expressed some concern about the recent increase in nontraditional lending products (such as interest-only, very long-term, and adjustable amortization mortgages). ${ }^{12}$ While the wider range of financial instruments will eventually enhance the efficiency of financial intermediation, some of these products might test in the short term the financial sophistication of some borrowers and lenders, particularly when agents' expectations may be based on the recent long period of record low interest rates. Also, although the average loan-to-value ratio (LTV) of bank's portfolios was relatively low, marginal LTVs had been rising. The Bank of Spain had accordingly stepped up vigilance in these areas, including through disclosure guidelines and consumer awareness initiatives, and indicated its readiness to consider additional prudential action if necessary.

\footnotetext{
${ }^{11}$ As this report was being finalized, the authorities discovered large-scale fraud by two nonfinancial investment companies, specializing in stamp trading - involving, according to some reports, €4-5 billion (about $1 / 2$ percent of GDP). The event, still unfolding, has prompted a review of regulations covering such collective investments in tangible assets. These fall outside the scope of financial sector regulators and supervisors, and are subject, rather, to consumer protection provisions.

${ }^{12}$ See Banco de España: Financial Stability Report (December 2005).
} 


\section{Box 6. FSAP-Selected Main Recommendations}

\section{A. Macrorelevant Recommendations}

- $\quad$ Tighten prudential requirements for nontraditional real estate loans to discourage excessive risk-taking.

- $\quad$ Adopt most conservative approaches under Basel II to contain credit institutions' industrial participations.

\section{B. Financial Sector Supervision}

- Strengthen the independence of financial sector supervisors by delegating more broadly the authority to issue norms and sanction violations to the respective agencies (ST 1/); separate insurance supervision from the Ministry of Economy (MT 2/).

- $\quad$ Clearly maintain the state-level supervisors' sole responsibility and powers regarding prudential supervision and regulation in the ongoing revisions of Autonomous Communities' Statutes. ST

- Introduce regulations to prevent a credit institution representative serving on the board of a nonfinancial company from taking part in the institution's decisions regarding that company. $M T$

\section{Issues Related to Savings Banks}

- $\quad$ Allow savings banks to merge freely, provided favorable ruling by the Bank of Spain on the viability of the merged institution. $M T$

- $\quad$ Promote means to raise high-quality capital, such as cuotas participativas. MT

- $\quad$ Reduce over time the public sector representation ceiling on savings banks' boards. $M T$

${ }^{1} S T$ (short term), or 6-12 months.

${ }^{2} M T$ (medium term), or $1-3$ years.

\section{Supervisory effectiveness and consistency with international best practices} would require enhancing the statutory independence of financial regulators. Specifically, while no instances of undue interference were found, the FSAP recommended that authority to issue norms and to sanction violations be delegated more broadly from the Ministry of Economy and from the Council of Ministers to the respective agencies. Formal independence of the insurance regulator is particularly constrained because it is directly part of the Ministry of Economy. The authorities concurred and expressed their intention to continue reforms in this direction. Since several of the regional Statutes of Autonomy are presently being revised, staff stressed the importance that these revisions preserve the sole 
role of the State-level supervisors in prudential oversight of financial institutions, minimizing the potential for conflicts. The government maintained that this was the case, countering staff concerns about possible wording ambiguities and stressing that long-standing jurisprudence safeguarded the role of State-level supervisors.

32. The mission discussed avenues to strengthen the governance and market orientation of savings banks (cajas). Savings banks have been a major force in the expansion of financial services over the last decades and currently account for about one third and one half of credit institutions' assets and deposits respectively. However, the nature of their ownership structure - which excludes private shareholders and provides for a large weight of political representation in their board of directors - requires a strong governance framework. The authorities noted with interest several staff proposals in this direction. These included reducing further the public sector representation ceiling in governing bodies; promoting means to raise high quality capital, such as the issuance of cuotas participativas ${ }^{13}$ to enhance market discipline; and removing restrictions to savings banks' mergers.

\section{The large industrial participations held by some credit institutions entail risks} associated with concentration of exposures and raise potential corporate governance problems. The authorities argued that concentration was partly driven by the size of the Spanish market and they underscored that ownership stakes had focused on the relatively stable utilities sector and had been highly profitable to date. Furthermore, the higher degree of risk was reflected in more stringent prudential requirements. Nonetheless, to mitigate risks going forward, staff supported consideration by the Bank of Spain of adopting the most conservative approaches to the treatment of industrial participations under Basel II. Also, staff pointed out the possibility of conflicts of interest and informational asymmetries between credit institutions and other investors, and recommended, as a minimum, introducing regulations to prevent a credit institution representative serving on the board of a nonfinancial company from taking part in the institution's decisions regarding that company.

\section{Staff APpraisal}

34. The decade-long expansion of the Spanish economy is continuing. The prolonged period of robust economic growth has raised average incomes, boosted job creation, and generated record fiscal revenues that have swung the general government balance into an appreciable surplus. This positive performance owes much to implementation of reforms since the early 1990s that opened the economy, enhanced its flexibility, and improved the macroeconomic policy framework, as well as to EMU membership and related low interest rates.

35. Macroeconomic imbalances are, however, intensifying. A record current account deficit is being driven by unsustainable domestic demand growth and widening cost and

\footnotetext{
${ }^{13}$ Marketable capital participations without voting rights.
} 
productivity differentials with trading partners, in addition to the effects of high oil prices. Buoyant demand and pricing power in sheltered markets are keeping inflation significantly above the euro-area average. Lackluster productivity growth is also weighing on competitiveness. The rising savings-investment imbalance of the nonfinancial private sector has been easily financed within EMU through the intermediation of a dynamic and efficient domestic financial system-but gross and net external liabilities have reached high levels, increasing the economy's exposure to interest rate risk.

36. The immediate growth outlook is buoyant, but accumulated imbalances and competitiveness losses weigh on prospects further out. Growth is expected to remain strong in 2006, although decelerating toward trend over the medium term, while the external deficit remains high. A continuation of brisk domestic demand growth and further competitiveness losses risks being followed by a pronounced private sector balance-sheet consolidation, as households reduce their high indebtedness. A combination of market rigidities and weak competitiveness may lead to a prolonged period of difficult, slow-growth adjustment.

37. Averting these risks requires stepping up the policy response. Regaining competitiveness within EMU will require, first and foremost, the implementation of a bold supply-oriented reform agenda, with an emphasis on enhancing product market competition and labor market flexibility. As these reforms take hold, fiscal policy needs to contribute by reining in domestic demand - in the absence of monetary policy, it is the only countercylical tool to this end. In addition, even though public finances are currently on a sound footing, their long-term sustainability hinges on early reform of the pension and healthcare systems. The current high-growth environment offers the best opportunity to implement these policies, minimizing their potential short-term costs.

38. The government's reform agenda to improve productivity and competitiveness merits the highest priority. Official plans are well-articulated, appropriately quantified, and are being carefully monitored. In their implementation, a greater emphasis should be placed on competition-based incentives. Liberalizing reforms that enhance contestability and create their own incentives for innovation are more effective than recourse to subsidy-based measures to promote R\&D. Accordingly, a key focus must be on further deregulating sheltered sectors. Openness in all its guises has served Spain well for many years, and the recent changes to takeover procedures in the energy sector merit reconsideration. If maintained, it is essential that they be implemented in a nondiscriminatory manner, consistent with Spain's good record in the transposition of EU directives. Furthermore, existing appointment procedures to sectoral regulatory agencies could be usefully reviewed, so as to fully guarantee their independence.

39. The labor market remains in need of further reform, the recent agreement on labor contracting notwithstanding. The response to Spain's uncommonly high rate of temporary employment lies, as shown by earlier reforms, in permanently reducing the rigidity and high dismissal costs of regular contracts - an aspect that remains essentially untouched by the latest agreement. Employment protection legislation thus continues to 
remain among the most restrictive in the OECD, restraining the necessary response to rising global competitive pressures. In addition, the social partners should now undertake in earnest discussions on modifications to the collective wage bargaining system, to better reflect relative productivity developments and encourage regional mobility.

\section{Excess domestic demand calls for greater expenditure-based fiscal restraint in} 2006 and 2007. The 2005 general government surplus - the first since the 1970s - is a notable achievement, and one that sets Spain apart from other euro area countriesincluding, most notably, its larger partners. But behind this achievement, underpinned by cyclically buoyant revenues, public spending has been growing at an excessively rapid pace, adding to demand pressures. The authorities' intention to allow the full play of automatic revenue stabilizers is welcome, but needs to be accompanied by spending restraint at all levels of government. Spending policies should be consistent with increasing the central government surplus and restoring a balanced position in regional and municipal governments in 2006, moving to a slight surplus in 2007-in keeping with the new BSL. Indeed, an exemplary implementation of the new framework in its first year of operation is crucial to its longer-term credibility

\section{Spain's highly decentralized system needs a robust budgetary framework to} promote fiscal discipline at all levels of government. Planned revisions to the BSL contain a number of welcome features, including greater countercyclical flexibility; the safeguarding of social security surpluses; and the proscription of state bail-outs for other levels of government. At the same time, however, some ambiguous wording and insufficiently precise specifications in the draft law risk allowing excessive leeway and scope for circumvention, complicating the framework's implementation - particularly in "good times" such as the present, when a move into surplus would be required at all levels of government.

\section{The current review of territorial financing arrangements should aim to augment} fiscal co-responsibility. To be successful, the ongoing decentralization of competencies must be accompanied by mechanisms that grant territorial governments significant powers to set their own taxes, and that create incentives to utilize such powers. This, rather than heavy reliance on the transfer of a higher share of taxes from the central government, which leaves incentives largely unchanged, should be the defining feature of the new financing system.

\section{Increased fiscal transparency is the necessary counterpart to the greater} flexibility granted by the revised BSL and new financing arrangements. Despite progress, including in implementing some of the 2005 fiscal ROSC recommendations, considerable scope remains for more extensive and timely publication of territorial governments' fiscal data, in particular concerning budget execution, quasi-fiscal activities, and contingent liabilities.

\section{Pension and healthcare reforms are required to ensure long-run fiscal} sustainability. The onset of the rising costs of aging - larger than elsewhere, even taking into account Spain's remarkable immigration phenomenon - is now only a decade or so away. The continued reform delays only raise the size of the measures that will eventually be 
needed. Reform measures will need to be broad-ranging, encompassing also an extension of the base period used to compute pensions, and the further development of private pension plans - whose tax treatment should be stable and predictable. Containing healthcare spending will also require reform measures, including a larger role for private provision and user copayments.

\section{The FSAP found a highly dynamic, well capitalized, and profitable financial} system under strong supervision. The main risks are associated with the rapid growth of mortgages and a potential downturn in the housing market, particularly if combined with an adverse macroeconomic scenario, though stress tests indicate a robust resilience to shocks. The increased Bank of Spain vigilance regarding nonconventional mortgages and other rapidly growing credit vehicles is well advised. As regards the prudential supervisory framework, further consistency with international best practices calls for increased independence of the three financial sectors supervisors - most particularly that of the insurance supervisor, formally the most constrained. Strong governance of the savings banks is also key, and could be enhanced by fostering the issuance of instruments that enhance market accountability, reducing the ceiling on government-nominated board directors, and removing obstacles to savings banks' mergers. The large industrial participations of some credit institutions can give rise to excessive exposure to equity markets and potential conflict of interests. As Basel II is introduced, it is recommended that the most restrictive interpretation regarding industrial participations be adopted. Also, clear separation should be introduced between credit institutions' management and board directors of nonfinancial companies in which they have a significant stake.

46. The authorities are encouraged to continue raising their ODA toward the 0.7 percent of GNP UN target (from 0.29 percent in 2005) and to actively contribute, within the EU, to a significant liberalization of international trade in the Doha round, including in agriculture and other sensitive areas. Statistical data provision is appropriate for surveillance. Nevertheless, improvements in timeliness and standardization of regional fiscal data should be a priority (Appendix III).

47. It is recommended that the next consultation be held on the standard 12-month cycle. 
Table 1. Spain: Main Economic Indicators, 2001-07 1/

\begin{tabular}{|c|c|c|c|c|c|c|c|}
\hline & \multirow[b]{2}{*}{2001} & \multirow[b]{2}{*}{2002} & \multirow[b]{2}{*}{2003} & \multirow[b]{2}{*}{2004} & \multirow[b]{2}{*}{$2005^{-}$} & \multicolumn{2}{|c|}{ Projections } \\
\hline & & & & & & 2006 & 2007 \\
\hline \multicolumn{8}{|l|}{ Demand and supply in constant prices } \\
\hline Gross domestic product & 3.5 & 2.7 & 3.0 & 3.1 & 3.4 & 3.3 & 3.2 \\
\hline Private consumption & 3.2 & 2.9 & 2.6 & 4.4 & 4.4 & 3.7 & 3.6 \\
\hline Public consumption & 3.9 & 4.5 & 4.8 & 6.0 & 4.5 & 5.1 & 3.8 \\
\hline Gross fixed investment & 4.5 & 3.3 & 5.6 & 4.9 & 7.3 & 5.8 & 4.4 \\
\hline Construction investment & 6.8 & 6.2 & 6.3 & 5.5 & 6.1 & 5.2 & 4.3 \\
\hline Other & 2.1 & 0.1 & 4.6 & 4.1 & 8.7 & 6.4 & 4.5 \\
\hline Stockbuilding (contribution to growth) & -0.1 & 0.0 & 0.0 & 0.0 & 0.0 & -0.1 & 0.0 \\
\hline Total domestic demand & 3.6 & 3.3 & 3.8 & 5.0 & 5.3 & 4.5 & 3.8 \\
\hline Net exports (contribution to growth) & -0.2 & -0.7 & -0.9 & -2.2 & -2.2 & -1.5 & -1.0 \\
\hline Exports of goods and services & 4.0 & 1.8 & 3.6 & 3.3 & 1.0 & 2.1 & 3.7 \\
\hline Imports of goods and services & 4.2 & 3.9 & 6.0 & 9.3 & 7.1 & 5.8 & 5.4 \\
\hline Potential output growth & 3.9 & 3.6 & 3.4 & 3.2 & 3.2 & 3.1 & 3.1 \\
\hline Output gap (percent of potential) & 1.0 & 0.1 & -0.3 & -0.4 & -0.2 & 0.0 & 0.1 \\
\hline Private credit growth & 11.8 & 12.3 & 14.2 & 17.9 & 27.2 & $\ldots$ & $\ldots$ \\
\hline \multicolumn{8}{|l|}{ Prices } \\
\hline GDP deflator & 4.2 & 4.4 & 4.0 & 4.1 & 4.4 & 3.6 & 3.1 \\
\hline HICP (average) 2/ & 2.8 & 3.6 & 3.1 & 3.1 & 3.4 & 3.4 & 3.1 \\
\hline Differential with euro area average & 0.5 & 1.4 & 1.0 & 0.9 & 1.2 & $\ldots$ & $\ldots$ \\
\hline \multicolumn{8}{|l|}{ Employment and wages } \\
\hline Unemployment rate (in percent) & 10.6 & 11.5 & 11.5 & 11.0 & 9.2 & 8.6 & 8.5 \\
\hline Unit labor cost in manufacturing (growth rate) & 2.5 & 1.8 & 2.3 & 2.5 & 2.5 & 2.5 & 2.5 \\
\hline Labor cost growth & 4.1 & 4.4 & 4.2 & 3.0 & 2.9 & $\ldots$ & $\ldots$ \\
\hline Employment growth & 3.2 & 2.4 & 2.6 & 2.6 & 3.6 & 3.2 & 2.7 \\
\hline \multicolumn{8}{|l|}{ Labor participation rate (in percent) $3 /$} \\
\hline Total & 53.0 & 54.3 & 55.5 & 56.4 & 57.4 & $\ldots$ & $\ldots$ \\
\hline Male & 66.2 & 67.0 & 67.7 & 68.1 & 68.8 & $\ldots$ & $\ldots$ \\
\hline Female & 40.4 & 42.2 & 43.8 & 45.2 & 46.4 & $\ldots$ & $\ldots$ \\
\hline \multicolumn{8}{|l|}{ Personal sector } \\
\hline Household savings (percent of disposable income) & 12.3 & 12.5 & 12.8 & 12.7 & 11.0 & $\ldots$ & ... \\
\hline \multicolumn{8}{|l|}{ Balance of payments (percent of GDP) } \\
\hline Trade balance $4 /$ & -5.7 & -5.0 & -5.1 & -6.4 & -7.6 & -8.3 & -8.6 \\
\hline Current account balance & -3.9 & -3.3 & -3.6 & -5.3 & -7.4 & -8.1 & -8.5 \\
\hline Official reserves excl. gold (US\$ billions) & 30.3 & 35.3 & 20.7 & 13.3 & 7.7 & 1.9 & -4.3 \\
\hline Nominal effective rate $(1990=100)$ & 72.5 & 74.2 & 76.8 & 77.6 & 76.3 & $\ldots$ & $\ldots$ \\
\hline Real effective rate $(1990=100)$ & 85.2 & 88.8 & 92.6 & 94.4 & 94.3 & $\ldots$ & $\ldots$ \\
\hline \multicolumn{8}{|l|}{ Public finance (percent of GDP) } \\
\hline General government balance & -0.5 & -0.3 & 0.0 & -0.1 & 1.1 & 0.9 & 0.7 \\
\hline Primary balance & 2.1 & 2.1 & 2.1 & 1.7 & 2.7 & 2.5 & 2.1 \\
\hline Structural balance $5 /$ & -1.2 & -0.3 & 0.1 & 0.8 & 1.1 & 0.9 & 0.7 \\
\hline Structural primary balance $5 /$ & 1.5 & 2.0 & 2.3 & 2.6 & 2.7 & 2.5 & 2.0 \\
\hline General government debt & 55.6 & 52.7 & 48.9 & 46.4 & 43.2 & 39.4 & 36.3 \\
\hline
\end{tabular}

Sources: IMF, World Economic Outlook; data provided by the authorites; and Fund staff estimates.

1/ Real national accounts variables are computed at constant 2000 prices. Thus, they might differ from the official national accounts data which, since 2005, use a methodology based on chained-linked volume indices.

2/ Year-on-year percentage change.

3/ Based on national definition (i.e., the labor force is defined as people older than 16).

4/ Excludes nonfactor services.

5/ Calculations exclude one-off adjustment amounting to 0.7 percent of GDP in 2004. 
Table 2. Spain: Fiscal Accounts, 2001-07

(In percent of GDP)

\begin{tabular}{|c|c|c|c|c|c|c|c|}
\hline & \multirow[b]{2}{*}{2001} & \multirow[b]{2}{*}{2002} & \multirow[b]{2}{*}{2003} & \multirow[b]{2}{*}{2004} & \multirow[b]{2}{*}{2005} & \multicolumn{2}{|c|}{ Projections } \\
\hline & & & & & & 2006 & 2007 \\
\hline Current revenues & 37.4 & 37.7 & 37.6 & 37.9 & 38.7 & 38.6 & 38.4 \\
\hline Indirect taxes & 11.0 & 11.2 & 11.5 & 11.9 & 12.1 & 11.9 & 11.9 \\
\hline Direct taxes & 10.0 & 10.4 & 10.1 & 10.2 & 11.0 & 10.9 & 10.8 \\
\hline Social security contributions & 13.0 & 13.0 & 13.0 & 13.0 & 13.0 & 13.1 & 13.1 \\
\hline Other current revenues & 3.4 & 3.1 & 2.9 & 2.7 & 2.6 & 2.7 & 2.6 \\
\hline Current expenditures & 33.9 & 33.8 & 33.7 & 33.7 & 33.3 & 33.6 & 33.5 \\
\hline Public consumption & 16.8 & 16.9 & 17.1 & 17.4 & 17.3 & 18.0 & 18.0 \\
\hline Current transfers & 11.7 & 11.8 & 11.7 & 11.7 & 11.6 & 11.8 & 11.8 \\
\hline Interest payments & 3.1 & 2.7 & 2.4 & 2.1 & 1.8 & 1.7 & 1.5 \\
\hline Other current expenditures & 1.3 & 1.4 & 1.5 & 1.5 & 1.6 & 1.1 & 1.2 \\
\hline Current balance & 3.5 & 3.9 & 3.9 & 4.2 & 5.3 & 5.0 & 4.9 \\
\hline Capital revenues & 0.6 & 0.7 & 0.7 & 0.8 & 0.7 & 0.7 & 0.7 \\
\hline Capital expenditures & 4.7 & 4.9 & 4.7 & 5.1 & 4.9 & 4.8 & 4.9 \\
\hline Gross fixed capital formation & 3.4 & 3.6 & 3.5 & 3.4 & 3.6 & 3.5 & 3.6 \\
\hline Capital transfers and other & 1.3 & 1.3 & 1.1 & 1.7 & 1.3 & 1.3 & 1.3 \\
\hline Capital balance & -4.1 & -4.2 & -4.0 & -4.3 & -4.3 & -4.0 & -4.1 \\
\hline Primary balance & 2.1 & 2.1 & 2.1 & 1.7 & 2.7 & 2.5 & 2.1 \\
\hline Overall balance & -0.5 & -0.3 & 0.0 & -0.1 & 1.1 & 0.9 & 0.7 \\
\hline Central government & -0.6 & -0.5 & -0.3 & -1.2 & 0.4 & 0.1 & 0.1 \\
\hline Territorial governments & -0.7 & -0.6 & -0.7 & 0.0 & -0.4 & -0.1 & -0.1 \\
\hline Social security & 0.8 & 0.8 & 1.0 & 1.0 & 1.1 & 0.9 & 0.7 \\
\hline Government debt & 55.6 & 52.7 & 48.9 & 46.4 & 43.2 & 39.4 & 36.3 \\
\hline \multicolumn{8}{|l|}{ Memorandum items: } \\
\hline Total revenue & 38.0 & 38.4 & 38.3 & 38.7 & 39.3 & 39.3 & 39.1 \\
\hline Total expenditure & 38.5 & 38.7 & 38.3 & 38.8 & 38.2 & 38.4 & 38.4 \\
\hline Structural primary balance $1 /$ & 1.5 & 2.0 & 2.3 & 2.6 & 2.7 & 2.5 & 2.0 \\
\hline Structural balance 1/ & -1.2 & -0.3 & 0.1 & 0.8 & 1.1 & 0.9 & 0.7 \\
\hline Structural expenditure & 39.2 & 38.8 & 38.2 & 37.9 & 38.2 & 38.4 & 38.4 \\
\hline Structural revenue & 38.0 & 38.4 & 38.3 & 38.7 & 39.3 & 39.3 & 39.1 \\
\hline
\end{tabular}

Sources: Cuentas Financieras, Bank of Spain; Intervención General de la Administración del Estado; and Fund staff projections.

1/ Calculations exclude one-off adjustments amounting to 0.7 percent of GDP in 2004. 


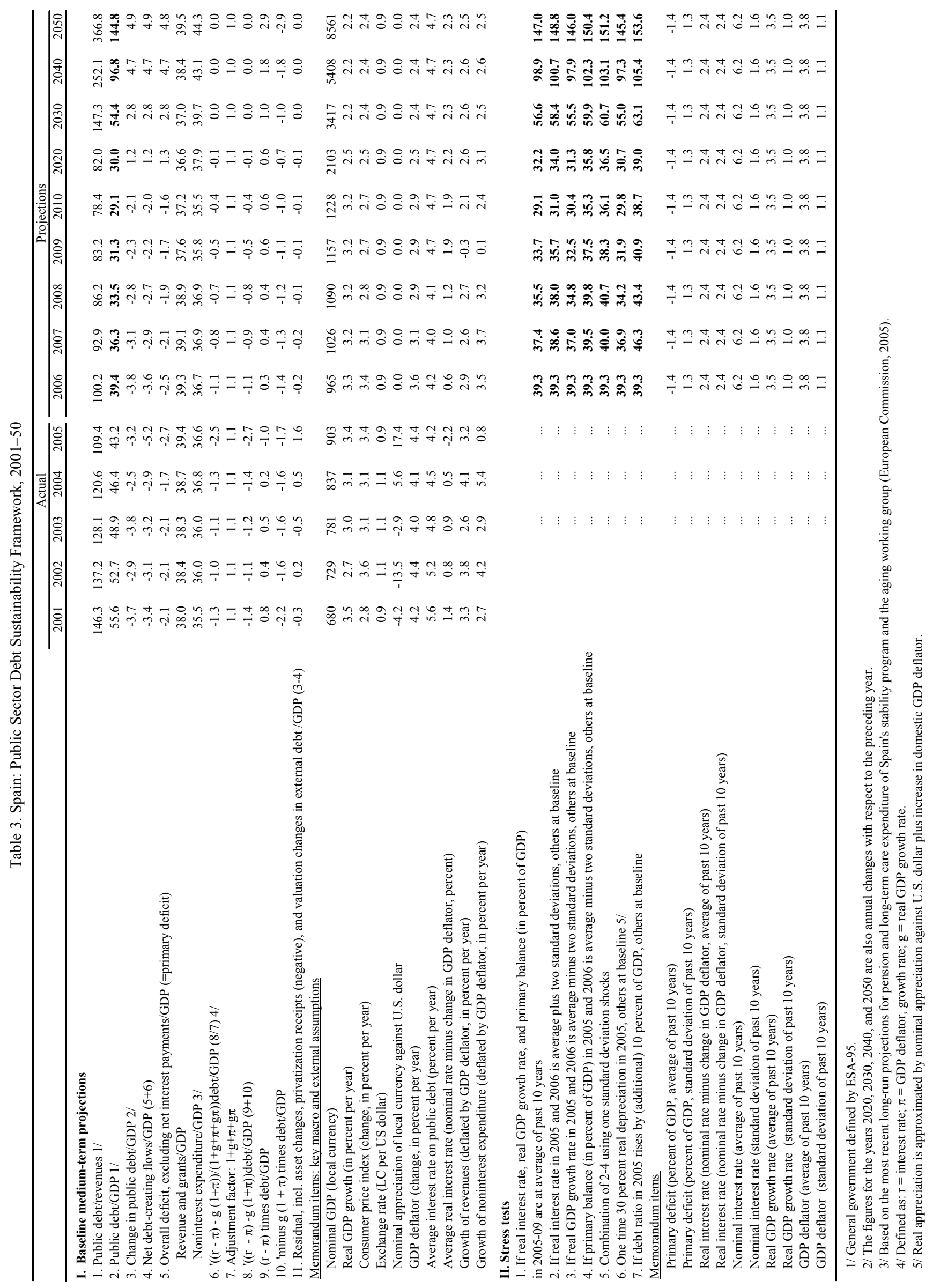


Table 4. Spain: Indicators of External and Financial Vulnerability, 2000-05 1/

(In percent of GDP, unless otherwise indicated)

\begin{tabular}{|c|c|c|c|c|c|c|}
\hline & 2000 & 2001 & 2002 & 2003 & 2004 & 2005 \\
\hline \multicolumn{7}{|l|}{ External indicators 1/ } \\
\hline Exports (annual percent change, in U.S. dollars) & 2.4 & 3.0 & 8.3 & 23.8 & 15.8 & 6.0 \\
\hline Imports (annual percent change, in U.S. dollars) & 6.1 & 0.9 & 7.1 & 24.9 & 22.4 & 11.5 \\
\hline Terms of trade (annual percent change) & -2.8 & 2.4 & 3.1 & 1.3 & 0.1 & -0.2 \\
\hline Current account balance (settlements basis) & -4.0 & -3.9 & -3.3 & -3.6 & -5.3 & -7.4 \\
\hline Capital and financial account balance & 4.0 & 3.9 & 3.2 & 3.5 & 5.2 & 7.5 \\
\hline Of which: Inward portfolio investment (debt securities, etc.) & 10.1 & 4.6 & 4.9 & 5.0 & 13.5 & 15.1 \\
\hline Inward foreign direct investment & 6.8 & 4.7 & 5.7 & 2.9 & 2.4 & 2.0 \\
\hline Other investment liabilities (net) & 5.7 & 6.5 & 1.8 & 6.6 & -2.7 & 3.4 \\
\hline Official reserves (in U.S. dollars, billions, end-of-period) 2/ & 31.8 & 30.3 & 35.3 & 20.7 & 13.3 & 7.7 \\
\hline Central Bank foreign liabilities (in U.S. dollars, billions) 2/ & 73.5 & 61.2 & 69.6 & 86.6 & 103.6 & 118.1 \\
\hline Foreign assets of the financial sector (in U.S. dollars, billions) & 303.6 & 312.2 & 342.5 & 427.3 & 527.5 & 689.9 \\
\hline Foreign liabilities of the financial sector (in U.S. dollars, billions) & 494.3 & 514.5 & 587.5 & 812.2 & 1033.3 & 1294.9 \\
\hline Official reserves in months of imports 2 / & 2.0 & 1.9 & 2.1 & 1.0 & 0.5 & 0.3 \\
\hline Net international investment position & -25.2 & -27.4 & -31.9 & -37.7 & -43.1 & -46.1 \\
\hline Gross liabilities & 124.2 & 129.1 & 133.4 & 141.6 & 153.2 & 170.6 \\
\hline Gross assets & 99.1 & 101.7 & 101.4 & 104.0 & 110.1 & 124.5 \\
\hline Public debt held by foreigners & 22.5 & 22.6 & 22.3 & 18.7 & 20.3 & 19.8 \\
\hline \multicolumn{7}{|l|}{ Financial market indicators } \\
\hline Public sector debt (Maastricht definition) & 59.3 & 55.6 & 52.7 & 48.9 & 46.4 & 43.2 \\
\hline 3-month T-bill yield & 4.6 & 3.9 & 3.3 & 2.2 & 2.2 & 2.2 \\
\hline 3-month T-bill yield (real) & 1.1 & 1.1 & -0.2 & -0.9 & -0.9 & -1.2 \\
\hline Stock market index ( General) & 994.8 & 853.4 & 723.6 & 706.4 & 863.3 & 1066.1 \\
\hline Share prices of financial institutions & $\ldots$ & 1061.1 & 869.9 & 808.7 & 959.1 & 906.6 \\
\hline Spread of 3-month T-bills with Germany (percentage points, end-of-period) & 0.3 & 0.3 & 0.4 & 0.2 & 0.2 & 0.2 \\
\hline \multicolumn{7}{|l|}{ Financial soundness indicators (core set) (in percent) $3 /$} \\
\hline Regulatory capital to risk-weighted assets & 12.4 & 12.9 & 12.5 & 12.6 & 12.3 & 12.2 \\
\hline Regulatory Tier I capital to risk-weighted assets & 9.1 & 9.0 & 8.6 & 8.5 & 8.1 & 8.1 \\
\hline Nonperforming credit to total gross credit $4 /$ & 1.0 & 0.9 & 1.0 & 0.9 & 0.7 & 0.6 \\
\hline Nonperforming credit net of provisions to total capital 5/ & -1.7 & 0.2 & 1.6 & 0.5 & -1.0 & $\ldots$ \\
\hline Credit to residents to total credit & 66.2 & 68.3 & 73.6 & 75.9 & 67.6 & 65.8 \\
\hline Credit to non-residents to total credit & 33.8 & 31.7 & 26.4 & 24.1 & 32.4 & 34.2 \\
\hline \multicolumn{7}{|l|}{ Of which (by region of residence): } \\
\hline European Union (except Spain) & 11.6 & 11.2 & 11.4 & 11.9 & 21.2 & 21.7 \\
\hline Latin America and the Caribbean & 17.0 & 15.9 & 11.5 & 9.2 & 7.5 & 8.2 \\
\hline Return on assets & 1.0 & 0.9 & 0.9 & 0.9 & 0.9 & 0.9 \\
\hline Return on equity & 15.3 & 13.5 & 12.1 & 13.2 & 14.1 & 16.9 \\
\hline Interest margin to gross income & 68.0 & 70.1 & 70.8 & 68.8 & 68.6 & 58.9 \\
\hline Noninterest expense to gross income 6/ & 63.6 & 61.0 & 59.8 & 58.0 & 57.1 & 53.7 \\
\hline Liquid assets to total assets (liquid asset ratio) 7/ & 34.7 & 33.2 & 30.9 & 30.3 & 30.4 & 34.3 \\
\hline Liquid assets to short-term liabilities 8 / & 76.7 & 74.8 & 70.2 & 67.9 & 66.7 & 75.6 \\
\hline Net open position in foreign exchange to Tier I capital & 24.5 & 24.0 & 13.5 & 8.6 & 11.5 & 11.4 \\
\hline Indebtedness of non-financial corporations (debt/value added) 9/ & 166.0 & 210.8 & 240.0 & 236.9 & 227.6 & 226.7 \\
\hline
\end{tabular}

Sources: Bank of Spain, Economic and Statistical Bulletins; CNMV; data provided by the authorities; and IMF, International Financial Statistics.

1/ The interpretation of some indicators is affected by the launch of monetary union in 1999.

2/ Reserves and foreign liabilities refer to the Bank of Spain, both before and after EMU.

3/ Deposit-taking institutions comprise commercial, savings and cooperative banks.

4/ Total gross credit does not include cash and central bank.

5/ Nonperforming credit net of specific provisions and those general and statistical provisions not included in Tier 2 capital to total regulatory capital. Latest Observation Dember 2004.

6/ Data series starting December 2005 denote the implementation of new accounting rules (IFRS).

7/ Excludes equity investments and fixed income portfolio instruments.

8 / Includes both fixed and variable income portfolio instruments.

9/ Debt excludes non-interest obligations and financing provided by suppliers. 
Table 5. Spain: Balance of Payments, 1999-2005

\begin{tabular}{|c|c|c|c|c|c|c|c|}
\hline & 1999 & 2000 & 2001 & 2002 & 2003 & 2004 & 2005 \\
\hline & \multicolumn{7}{|c|}{ (In billions of euros) } \\
\hline Current account balance & -16.9 & -25.1 & -26.3 & -23.8 & -27.9 & -44.2 & -66.6 \\
\hline Trade balance & -10.8 & -19.2 & -15.6 & -13.9 & -16.5 & -31.9 & -46.3 \\
\hline Exports of goods & 106.0 & 125.6 & 131.2 & 134.8 & 139.8 & 149.0 & 156.4 \\
\hline Imports of goods & 135.9 & 165.8 & 169.8 & 171.3 & 179.6 & 202.6 & 225.3 \\
\hline Balance of nonfactor services & 19.2 & 21.0 & 23.0 & 22.6 & 23.3 & 21.8 & 22.6 \\
\hline Balance of factor income & -9.0 & -7.4 & -12.5 & -12.3 & -11.6 & -12.1 & -17.2 \\
\hline Balance of current transfers & 2.8 & 1.4 & 1.8 & 2.4 & 0.2 & -0.1 & -3.1 \\
\hline Balance of capital and financial account & 17.9 & 25.0 & 26.8 & 23.7 & 27.0 & 43.3 & 67.5 \\
\hline Foreign direct investment & -24.1 & -20.2 & -5.3 & 6.9 & -1.4 & -28.8 & -12.7 \\
\hline Gross Inflows & 17.6 & 43.0 & 31.7 & 41.7 & 23.0 & 19.9 & 18.5 \\
\hline Gross Outflows & 41.7 & 63.2 & 37.0 & 34.8 & 24.4 & 48.8 & 31.2 \\
\hline Portfolio & -2.0 & -1.4 & -18.9 & 4.2 & -41.8 & 80.8 & 40.5 \\
\hline Other investment & 16.3 & 38.1 & 43.8 & 8.3 & 48.2 & -22.4 & 30.3 \\
\hline Capital transfers & 6.7 & 5.2 & 5.7 & 7.8 & 8.5 & 8.6 & 8.1 \\
\hline Reserve assets & 21.0 & 3.3 & 1.6 & -3.6 & 13.6 & 5.1 & 1.4 \\
\hline \multirow[t]{2}{*}{ Errors and omissions } & -0.9 & 0.2 & -0.5 & 0.2 & 0.9 & 0.9 & -0.9 \\
\hline & \multicolumn{7}{|c|}{ (In percent of GDP) } \\
\hline Current account balance & -2.9 & -4.0 & -3.9 & -3.3 & -3.6 & -5.3 & -7.4 \\
\hline Trade balance & -1.9 & -3.0 & -2.3 & -1.9 & -2.1 & -3.8 & -5.1 \\
\hline Exports of goods & 18.3 & 19.9 & 19.3 & 18.5 & 17.9 & 17.8 & 17.3 \\
\hline Imports of goods & 23.4 & 26.3 & 25.0 & 23.5 & 23.0 & 24.2 & 24.9 \\
\hline Balance of nonfactor services & 3.3 & 3.3 & 3.4 & 3.1 & 3.0 & 2.6 & 2.5 \\
\hline Balance of factor income & -1.5 & -1.2 & -1.8 & -1.7 & -1.5 & -1.4 & -1.9 \\
\hline Balance of current transfers & 0.5 & 0.2 & 0.3 & 0.3 & 0.0 & 0.0 & -0.3 \\
\hline Balance of capital and financial account & 3.1 & 4.0 & 3.9 & 3.2 & 3.5 & 5.2 & 7.5 \\
\hline Foreign direct investment & -4.1 & -3.2 & -0.8 & 0.9 & -0.2 & -3.4 & -1.4 \\
\hline Gross Inflows & 3.0 & 6.8 & 4.7 & 5.7 & 2.9 & 2.4 & 2.0 \\
\hline Gross Outflows & 7.2 & 10.0 & 5.4 & 4.8 & 3.1 & 5.8 & 3.4 \\
\hline Portfolio & -0.3 & -0.2 & -2.8 & 0.6 & -5.4 & 9.6 & 4.5 \\
\hline Other investment & 2.8 & 6.0 & 6.4 & 1.1 & 6.2 & -2.7 & 3.3 \\
\hline Reserve assets & 3.6 & 0.5 & 0.2 & -0.5 & 1.7 & 0.6 & 0.2 \\
\hline Errors and omissions & -0.2 & 0.0 & -0.1 & 0.0 & 0.1 & 0.1 & -0.1 \\
\hline
\end{tabular}

Source: Bank of Spain. 
Table 6. Spain: Medium-Term Projections of the Balance of Payments

\begin{tabular}{|c|c|c|c|c|c|c|c|c|}
\hline & 2004 & 2005 & 2006 & 2007 & 2008 & 2009 & 2010 & 2011 \\
\hline & \multicolumn{8}{|c|}{ (In billions of euros) } \\
\hline 1. Current Account & -44.2 & -66.6 & -78.4 & -87.7 & -95.6 & -101.0 & -106.4 & -114.8 \\
\hline 1.a. Trade Balance of Goods and Services & -31.9 & -46.3 & -56.1 & -64.0 & -70.4 & -76.7 & -83.1 & -90.1 \\
\hline Exports of Goods and Services & 218.3 & 231.8 & 244.1 & 256.5 & 271.5 & 287.5 & 304.6 & 322.5 \\
\hline Exports of Goods & 149.0 & 156.4 & 162.1 & 170.3 & 180.3 & 190.9 & 202.3 & 214.1 \\
\hline Exports of Services & 69.4 & 75.4 & 82.0 & 86.2 & 91.2 & 96.6 & 102.3 & 108.3 \\
\hline Imports of Goods and Services & -250.2 & -278.1 & -300.2 & -320.5 & -341.9 & -364.3 & -387.8 & -412.6 \\
\hline Imports of Goods & -202.6 & -225.3 & -242.2 & -258.6 & -275.8 & -293.9 & -312.8 & -332.9 \\
\hline Imports of Services & -47.6 & -52.8 & -58.0 & -61.9 & -66.1 & -70.4 & -74.9 & -79.7 \\
\hline 1.b. Balance of Factor Income & -12.1 & -17.2 & -18.4 & -19.6 & -20.8 & -20.8 & -20.8 & -22.1 \\
\hline 1.c. Balance of Current Transfers & -0.1 & -3.1 & -3.9 & -4.1 & -4.4 & -3.5 & -2.5 & -2.6 \\
\hline 2. Capital Account & 8.4 & 8.0 & 8.7 & 7.2 & 5.5 & 3.5 & 2.5 & 2.6 \\
\hline 3. Financial Account & 34.9 & 59.6 & 69.6 & 80.5 & 90.1 & 97.6 & 104.0 & 112.2 \\
\hline \multirow[t]{2}{*}{ 4. Net International Investment Position } & -359.5 & -416.7 & -486.4 & -566.9 & -657.0 & -754.5 & -858.5 & -970.7 \\
\hline & \multicolumn{8}{|c|}{ (In percent of GDP) } \\
\hline 1. Current Account & -5.3 & -7.4 & -8.1 & -8.5 & -8.7 & -8.7 & -8.7 & -8.8 \\
\hline 1.a. Trade Balance of Goods and Services & -3.8 & -5.1 & -5.8 & -6.2 & -6.4 & -6.6 & -6.8 & -6.9 \\
\hline Exports of Goods and Services & 26.1 & 25.6 & 25.2 & 24.9 & 24.8 & 24.8 & 24.8 & 24.8 \\
\hline Exports of Goods & 17.8 & 17.3 & 16.8 & 16.6 & 16.5 & 16.5 & 16.5 & 16.5 \\
\hline Exports of Services & 8.3 & 8.3 & 8.5 & 8.4 & 8.3 & 8.3 & 8.3 & 8.3 \\
\hline Imports of Goods and Services & -29.9 & -30.8 & -31.0 & -31.1 & -31.3 & -31.5 & -31.6 & -31.8 \\
\hline Imports of Goods & -24.2 & -24.9 & -25.0 & -25.1 & -25.2 & -25.4 & -25.5 & -25.6 \\
\hline Imports of Services & -5.7 & -5.8 & -6.0 & -6.0 & -6.0 & -6.1 & -6.1 & -6.1 \\
\hline 1.b. Balance of Factor Income & -1.4 & -1.9 & -1.9 & -1.9 & -1.9 & -1.8 & -1.7 & -1.7 \\
\hline 1.c. Balance of Current Transfers & 0.0 & -0.3 & -0.4 & -0.4 & -0.4 & -0.3 & -0.2 & -0.2 \\
\hline 2. Capital Account & 1.0 & 0.9 & 0.9 & 0.7 & 0.5 & 0.3 & 0.2 & 0.2 \\
\hline 3. Financial Account & 4.2 & 6.6 & 7.2 & 7.8 & 8.2 & 8.4 & 8.5 & 8.6 \\
\hline 4. Net International Investment Position & -42.9 & -46.1 & -50.3 & -55.1 & -60.1 & -65.2 & -70.0 & -74.8 \\
\hline \multicolumn{9}{|l|}{ Memorandum: } \\
\hline Trade Balance of Goods & -6.4 & -7.6 & -8.3 & -8.6 & -8.7 & -8.9 & -9.0 & -9.1 \\
\hline
\end{tabular}


Figure 1. Spain: Real Sector, 2000-05

Real GDP Growth

(Year-on-year percentage change)


GDP Per Capita as a Share of Euro Area Average (current prices, in percent)


Sources: Bank of Spain and Eurostat. 
Figure 2. Spain: Headline and Core Inflation, 1997-2006 (In percent)

HICP



Differential for Spain vs. Euro Area

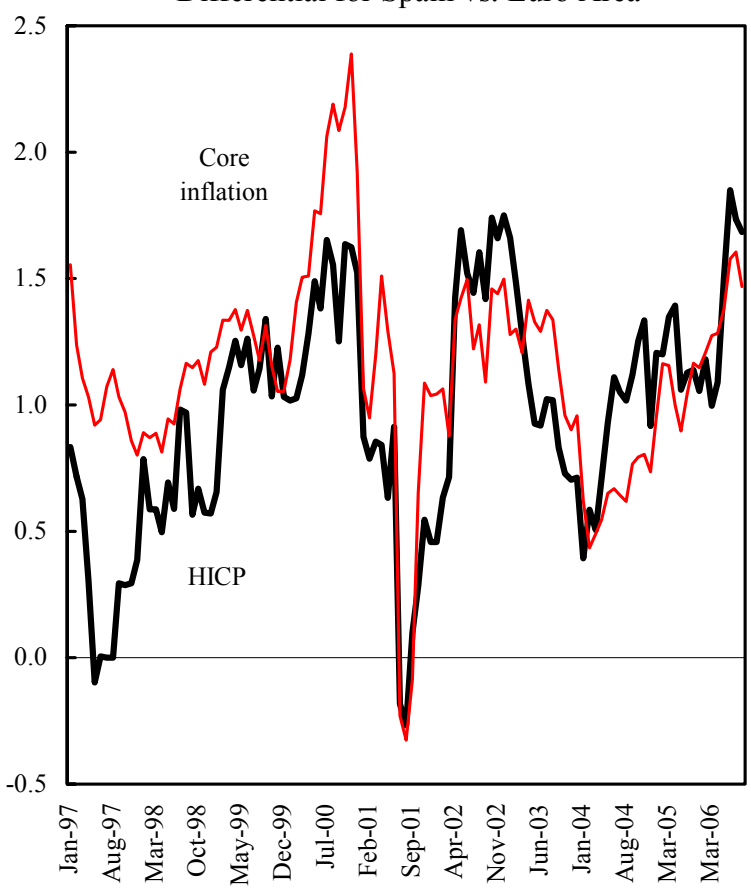

Core Inflation

(Annual rate of change)

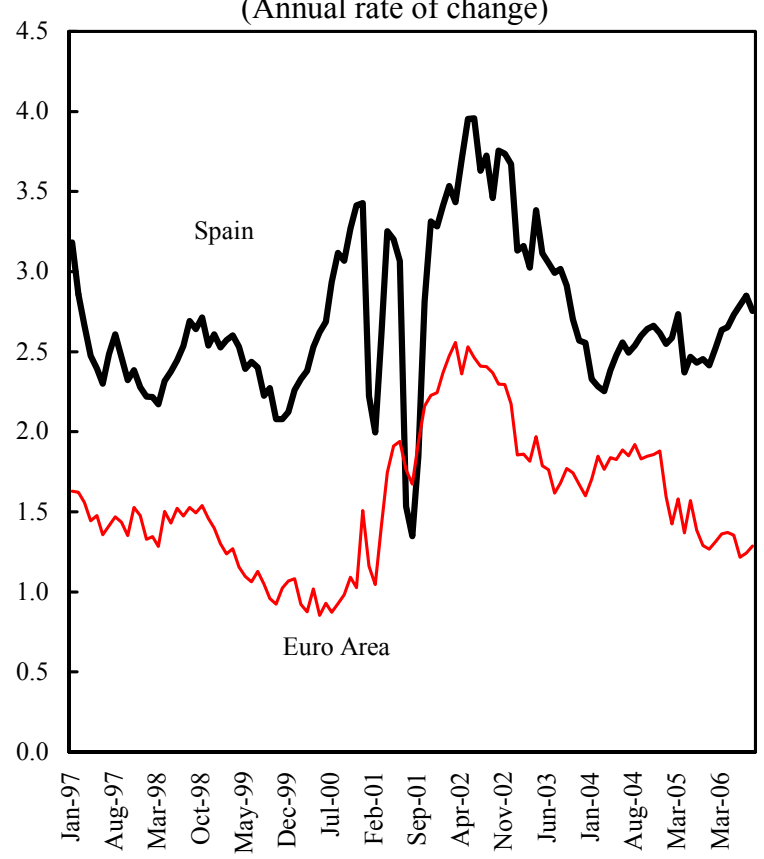

Cumulative Differential for Spain vs. Euro

Area

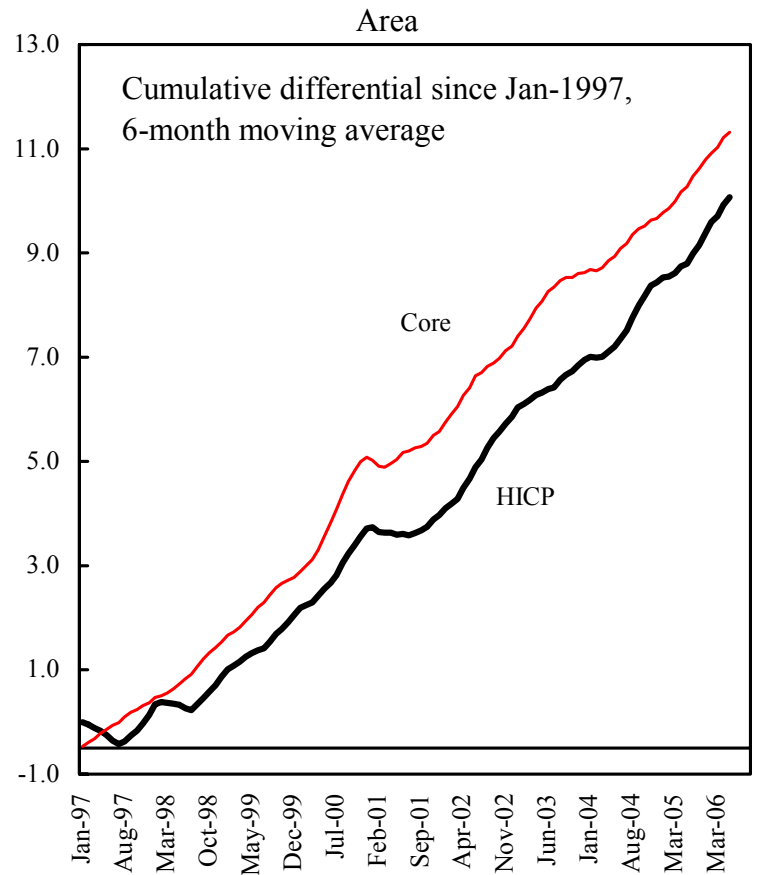

Source: Eurostat. 
Figure 3. Spain: Competitiveness and Exports, 1990-2006
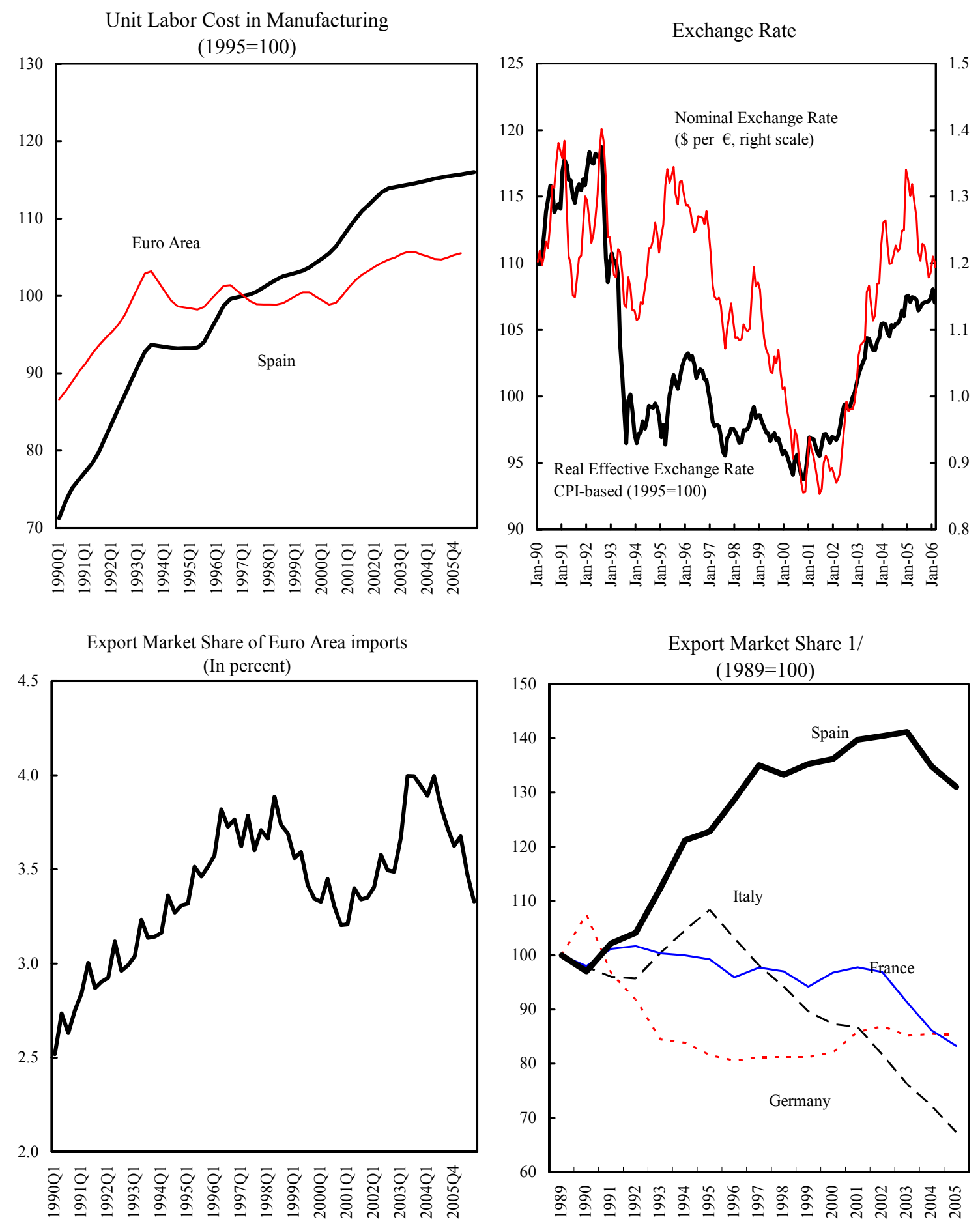

Sources: IMF, International Financial Statistics; IMF, Direction of Trade; IMF, World Economic Outlook; Bank of Italy; ISTAT; and Organization for Economic Cooperation and Development.

1/ As measured by real growth of exports of goods and nonfactor services less growth of import demand in partner countries. 
Figure 4. Spain: Housing and Mortgage Credit
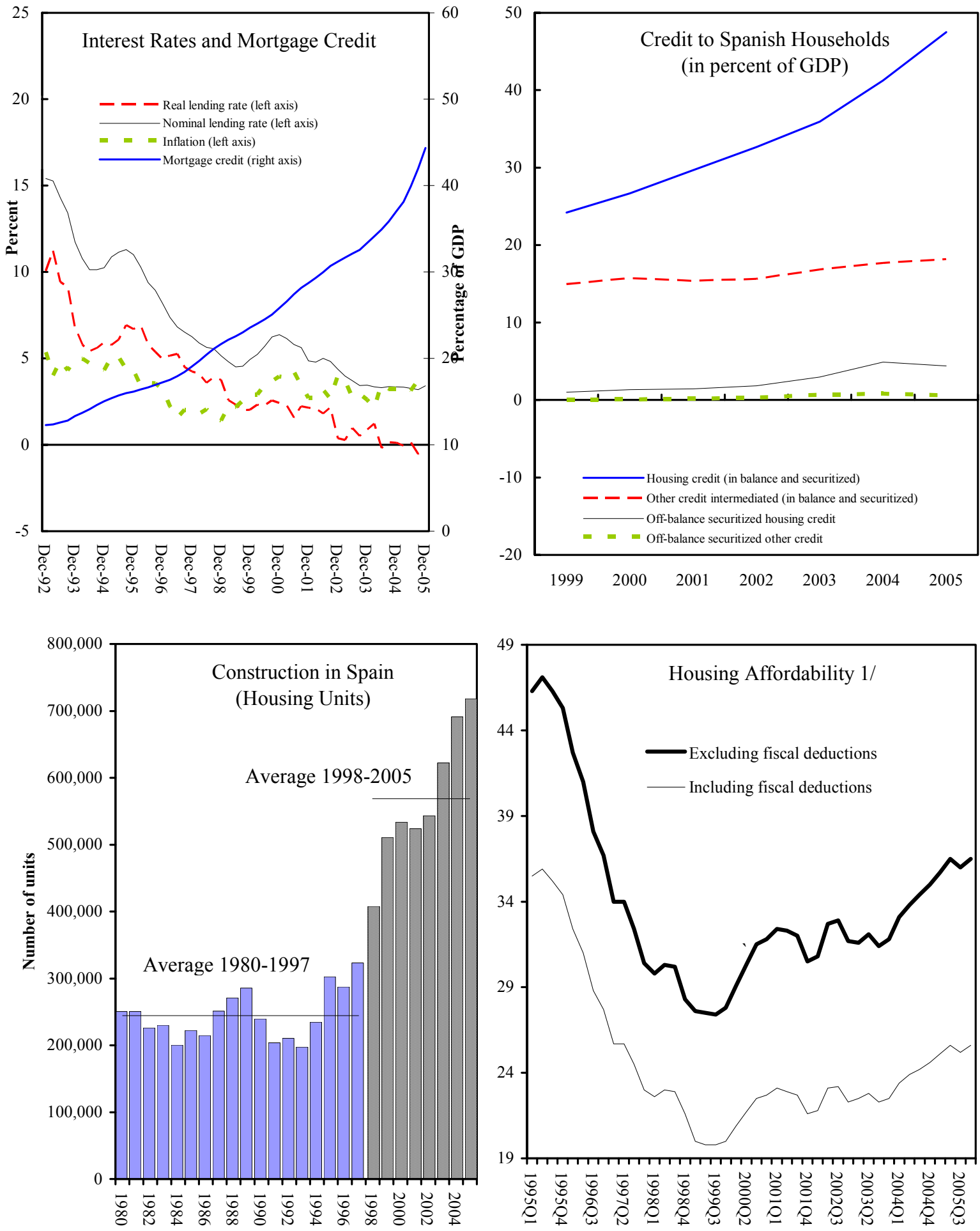

Source:

1/ Mortgage payments in the first year as percent of household's disposable income, assuming an initial down payment of 20 percent (loan-to-value ratio of 80 percent). 
Figure 5. Spain: Financing of the Current and Capital Account Deficits
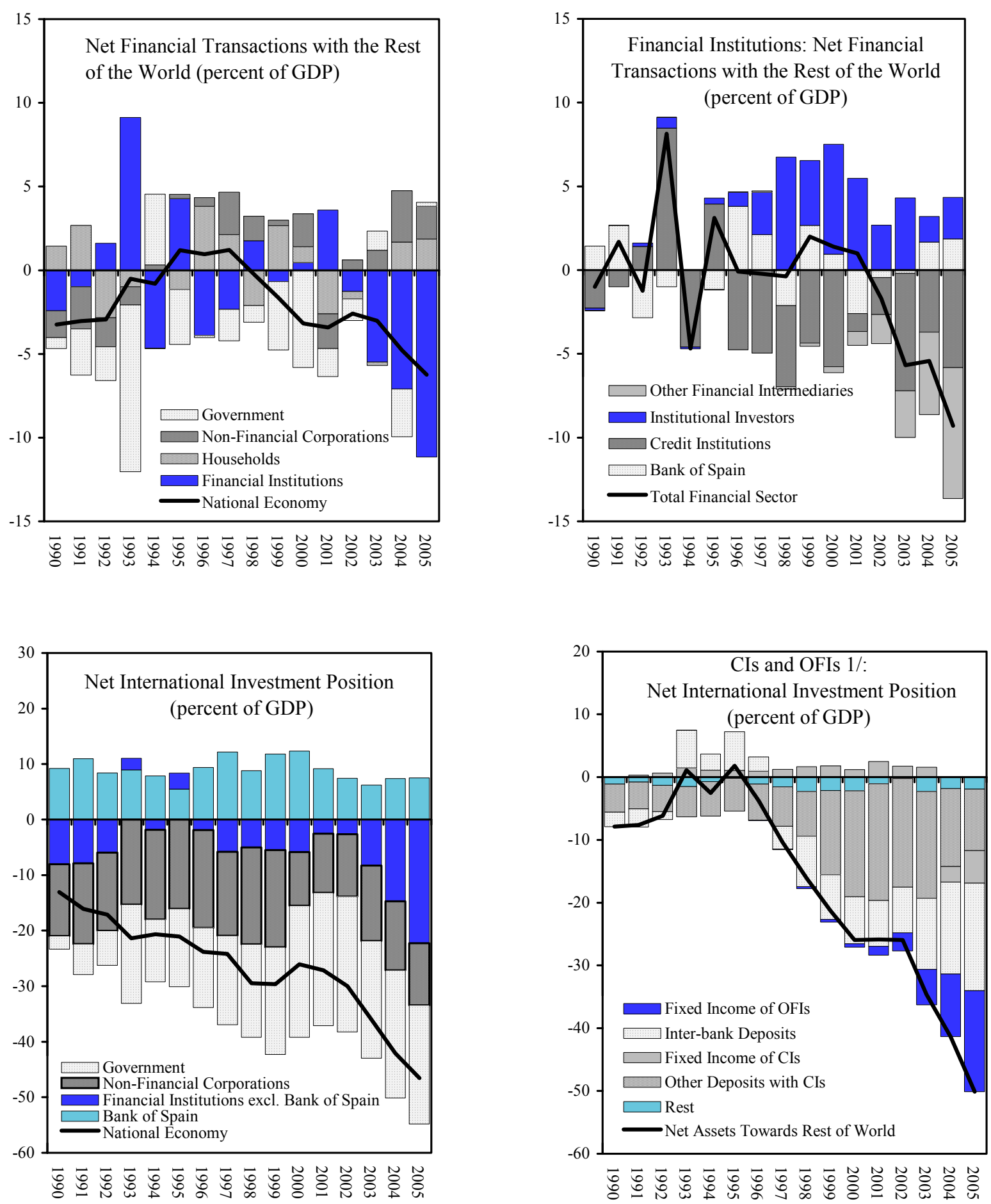

Source: Bank of Spain

1/ Credit institutions and Other Financial Intermediaries. Other financial intermediaries include, among others, securitization funds and structured finance vehicles. 
Figure 6. Spain: Financial Market Indicators
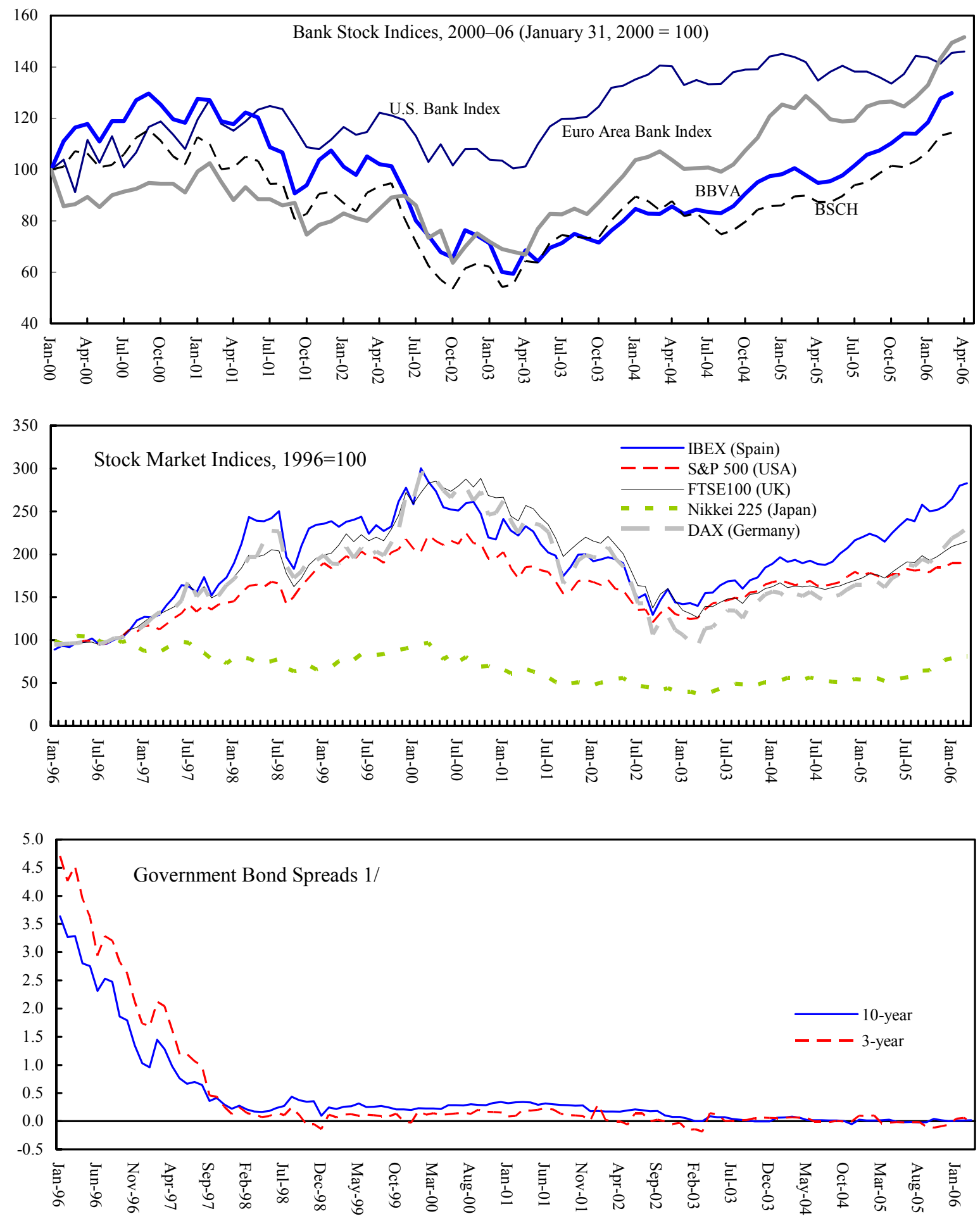

Source: Bloomberg, Fund Staff Calculations

1/ Difference on return between Spanish and German government bonds of the given maturity. 


\section{Spain: Fund Relations}

(As of April 30, 2006)

I. Membership Status: Spain became a member of the Fund on September 15, 1958. On July 15, 1986, Spain accepted the obligations of Article VIII Sections 2, 3, and 4 of the Articles of Agreement.

II. General Resources Account:

Quota

Fund holdings of currency

Reserve position

$\begin{array}{cc}\text { SDR Million } & \text { \% Quota } \\ 3,048.90 & 100.00 \\ 2,709.07 & 88.85 \\ 339.84 & 11.15\end{array}$

III. SDR Department:

Net cumulative allocation

$\begin{array}{ll}\text { SDR Million } & \text { \% Allocation } \\ 298.81 & 100.00 \\ 216.32 & 72.39\end{array}$

Holdings

216.32

72.39

IV. Outstanding Purchases and Loans: None

V. Latest Financial Arrangements: None

VI. Projected Payments to Fund:

\begin{tabular}{lccccc}
\multicolumn{7}{c}{ Forthcoming } \\
\hline & 2006 & 2007 & 2008 & 2009 & 2010 \\
\cline { 2 - 6 } Principal & & & & & \\
Charges/Interest & 2.13 & 2.91 & 2.92 & 2.91 & 2.91 \\
$\quad$ Total & 2.13 & 2.91 & 2.92 & 2.91 & 2.91 \\
\hline
\end{tabular}

VII. Exchange Rate Arrangement: Spain entered the final stage of European Economic and Monetary Union on January 1,1999, at a rate of 166.386 Spanish pesetas per euro.

Spain maintains an exchange system free of restrictions on the making of payments and transfers for current international transactions, except for the exchange restrictions imposed by Spain solely for the preservation of national or international security that have been notified to the Fund pursuant to Executive Board Decision No. 144-(52/51).

VIII. Article IV Consultations: The last Article IV consultation was concluded on February 9, 2005. Spain is on the standard 12-month consultation cycle. 


\section{Spain: Statistical Issues}

Areas for improvement include:

- General government. Historical revisions, preliminary estimates, and planned fiscal accounts data should be made available to the public shortly after being sent to Eurostat in March and September. In addition, major revisions should be fully documented. The reconciliation of cash and accrual general government data are unclear. Details of these calculations would enhance monitoring at higher frequencies.

- $\quad$ Territorial governments. The reporting and transparency of fiscal outcomes has improved with the adoption of key recommendations of the 2005 fiscal ROSC. Nevertheless, expenditure and revenue details remain wanting and timeliness is still an issue-regional fiscal outcomes for 2004 are now available, but the 2005 outcomes are yet to be published. Also, the reporting of PPP-related operations at all levels of government should be improved. The importance of monitoring fiscal developments at the territorial level is heightened by recent deviations from their fiscal targets, and is essential for the implementation of the Budgetary Stability Law.

- Labor market. Two different measures of unemployment are reported by the authorities (so-called "registered" and "survey" unemployment), which vary substantially. Data on employment growth are distorted by the flow of workers from the informal to the formal labor force, which complicates the calculation of productivity growth and hence unit labor costs.

- $\quad$ National Accounts. These have been revised in line with the 1995 version of the European System of Accounts. Chain-linked national accounts in base year 2000 have been published since May 2005, but pre-1995 data have not been revised yet. 


\section{Country: Table of Common Indicators Required for Surveillance (As of May 15, 2006)}

\begin{tabular}{|c|c|c|c|c|c|}
\hline & $\begin{array}{c}\text { Date of } \\
\text { latest } \\
\text { observation }\end{array}$ & $\begin{array}{l}\text { Date } \\
\text { received }\end{array}$ & $\begin{array}{c}\text { Frequency } \\
\text { of } \\
\text { Data }^{6}\end{array}$ & $\begin{array}{l}\text { Frequency } \\
\text { of } \\
\text { Reporting }^{6}\end{array}$ & $\begin{array}{c}\text { Frequency } \\
\text { of } \\
\text { Publication } \\
6\end{array}$ \\
\hline Exchange Rates & $5 / 15 / 06$ & $5 / 15 / 06$ & Daily & Daily & Daily \\
\hline $\begin{array}{l}\text { International Reserve Assets and Reserve Liabilities } \\
\text { of the Monetary Authorities } 1\end{array}$ & $02 / 06$ & 03/06 & Monthly & Monthly & Monthly \\
\hline Reserve/Base Money & $02 / 06$ & $03 / 06$ & Monthly & Monthly & Monthly \\
\hline Broad Money & $02 / 06$ & 03/06 & Monthly & Monthly & Monthly \\
\hline Central Bank Balance Sheet & $02 / 06$ & 03/06 & Monthly & Monthly & Monthly \\
\hline Consolidated Balance Sheet of the Banking System & $01 / 06$ & 03/06 & Monthly & Monthly & Monthly \\
\hline Interest Rates ${ }^{2}$ & $5 / 15 / 06$ & $5 / 15 / 06$ & Daily & Daily & Daily \\
\hline Consumer Price Index & 03/06 & $04 / 06$ & Monthly & Monthly & Monthly \\
\hline $\begin{array}{l}\text { Revenue, Expenditure, Balance and Composition of } \\
\text { Financing }{ }^{3} \text { - General Government }\end{array}$ & 2005 & $3 / 06$ & Annual & Annual & Annual \\
\hline $\begin{array}{l}\text { Revenue, Expenditure, Balance and Composition of } \\
\text { Financing }{ }^{3} \text { - Central Government }\end{array}$ & 2005 & $3 / 06$ & Annual & Annual & Annual \\
\hline $\begin{array}{l}\text { Stocks of Central Government and Central } \\
\text { Government-Guaranteed Debt }\end{array}$ & $02 / 06$ & 03/06 & Monthly & Monthly & Monthly \\
\hline External Current Account Balance & $01 / 06$ & $04 / 06$ & Monthly & Monthly & Monthly \\
\hline Exports and Imports of Goods and Services & $01 / 06$ & $04 / 06$ & Monthly & Monthly & Monthly \\
\hline GDP/GNP & Q4-06 & 03/06 & Quarterly & Quarterly & Quarterly \\
\hline Gross External Debt & Q4-06 & $02 / 06$ & Quarterly & Quarterly & Quarterly \\
\hline
\end{tabular}

${ }^{1}$ Includes reserve assets pledged or otherwise encumbered as well as net derivative positions.

${ }^{2}$ Both market-based and officially determined, including discount rates, money market rates, rates on treasury bills, notes and bonds.

${ }^{3}$ Foreign, domestic bank, and domestic nonbank financing.

${ }^{4}$ The general government consists of the central government (budgetary funds, extra budgetary funds, and social security funds) and state and local governments.

${ }^{5}$ Including currency and maturity composition.

${ }^{6}$ Daily (D), weekly (W), monthly (M), quarterly (Q), annually (A), irregular (I); and not available (NA). 
INTERNATIONAL MONETARY FUND

SPAIN

Staff Report for the 2006 Article IV Consultation

Supplementary Information

Prepared by the European Department

Approved by Susan M. Schadler and G. Russell Kincaid

June 7, 2006

1. This supplement incorporates information that has become available after the circulation of the staff report. These developments do not alter the thrust of the staff appraisal.

\section{GDP growth remained buoyant}

in the first quarter of 2006: despite some deceleration in private spending and a pickup in exports, the current account deficit widened further, and inflation remained high. ${ }^{1}$ Output grew by $3 \frac{1}{2}$ percent in the year to $2006: \mathrm{Q} 1$ (3.1 percent quarter-on-quarter annualized and seasonally adjusted). Data show a quarter-on-quarter deceleration in private consumption and, less markedly, investment. As in other EU countries, both export and import growth rose in Q1. The latest current account data indicate a widening of the deficit by $€ 3.2$ billion ( 0.35 percent of 2005 GDP) in the first two months of 2006 with respect to the same period of 2005. In May, headline inflation
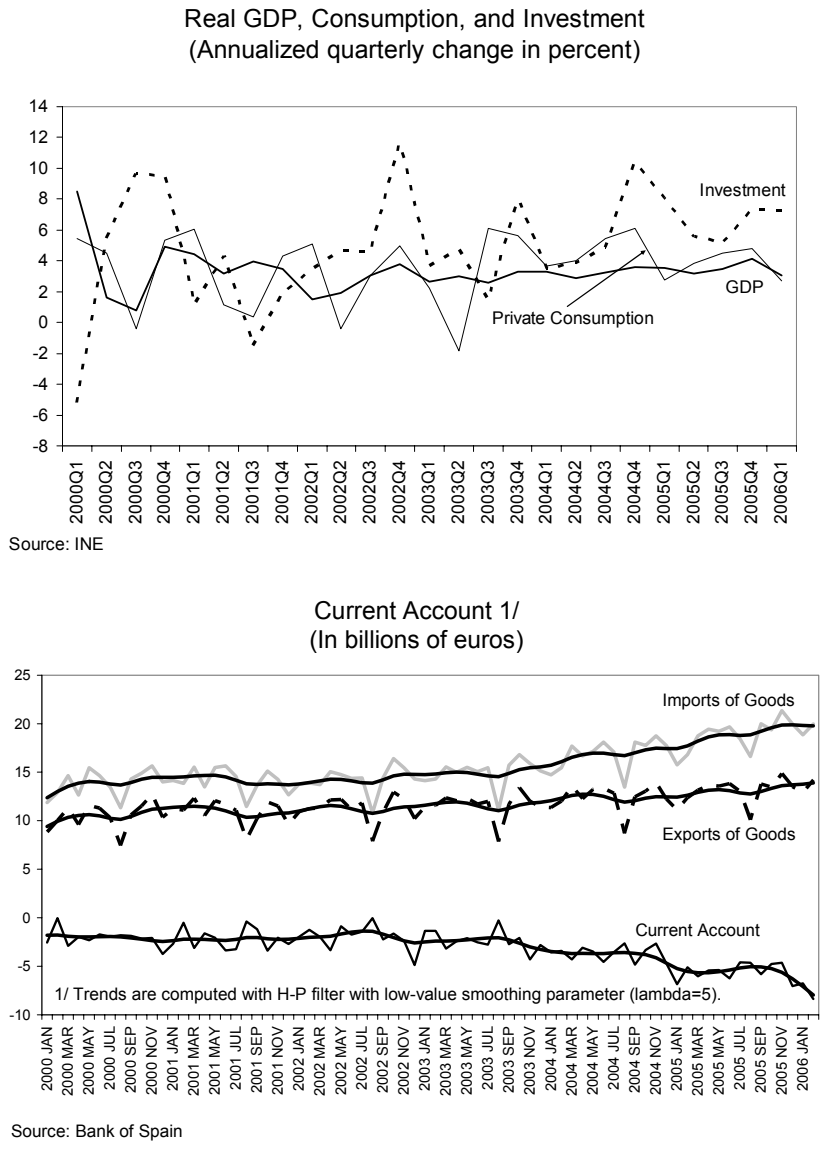

\footnotetext{
${ }^{1}$ The new information does not materially alter the staff report's projections, but will be incorporated—along with revised global assumptions - in the new WEO round currently underway.
} 
(4.1 percent) and the inflation differential with the euro area (1.6 percentage points) remained high.

3. In early June, the government announced medium-term fiscal targets through 2009, as well as the central government's expenditure ceiling for 2007. While the authorities did not update the official estimate for the 2006 general government outcome (a surplus of 0.9 percent of GDP, set in the December 2005 Stability Program), fiscal data so far this year confirm the likelihood of a better outcome (anticipated in the Staff Report, $\uparrow 14$ ). The announced target for 2007, if implemented as announced, would imply a moderately

\begin{tabular}{lrrrrr}
\multicolumn{6}{c}{$\begin{array}{c}\text { Official Fiscal Projections 1/ } \\
\text { (In percent of GDP) }\end{array}$} \\
\hline \multicolumn{7}{c}{2005} & 2006 & 2007 & 2008 & 2009 \\
\hline General government balance & 1.1 & 0.9 & 0.7 & 0.8 & 0.8 \\
Central government & 0.4 & 0.1 & 0.2 & 0.2 & 0.2 \\
Social security & 1.1 & 0.9 & 0.7 & 0.6 & 0.6 \\
Territorial governments & -0.4 & -0.1 & -0.2 & 0.0 & 0.0 \\
\hline
\end{tabular}

Sources: Ministry of Finance and Economy, and authorities' projections.

1/ Actual for 2005; Stability Program (December, 2005) for 2006; and Council of Ministers (June 2, 2006) for 2007-09. expansionary stance - partly attributed to the entry into effect of the tax reform (see Staff Report, ๆ22) - and a continuation of the territorial governments' deficit through 2007. The latter deficit, in the first year of application of the new Budget Stability Law, is officially ascribed to deficits in a number of regions and municipalities that are being addressed under phased adjustment plans. Finally, the government announced its intention to contain central government spending growth in 2007 at 6.7 percent, in line with nominal GDP. These targets are largely consistent with the policy intentions outlined at the time of the discussions andwhile commendably envisaging surpluses through 2009 - fall short of the expenditure-based fiscal restraint recommended in the Staff Report (\$40) to help curb excess domestic demand in the short term. As in the past, it is however likely — and desirable — that, with the full play of automatic revenue stabilizers (to which the authorities are committed), budget execution will exceed the announced targets.

\section{The social partners and the government have reached agreement on a limited} pension reform. The reform includes incentives to prolong the effective working life, marginally extends the effective minimum contribution period (from 12.8 to 15 years), and consolidates the agricultural and self-employed regimes into the general system. It also extends the coverage of widowers' pensions and increases pensions of those retired early as a consequence of dismissal. It leaves the base period to compute pensions untouched. Overall, while the agreement represents a helpful move in the direction advocated by staff, the longterm sustainability of the social security accounts will require further action. 


\section{INTERNATIONAL MONETARY FUND}

\section{Public Information Notice}

EXTERNAL

RELATIONS

DEPARTMENT
Public Information Notice (PIN) No. 06/65

FOR IMMEDIATE RELEASE

June 14, 2006
International Monetary Fund $70019^{\text {th }}$ Street, NW

Washington, D. C. 20431 USA

\section{IMF Executive Board Concludes 2006 Article IV Consultation with Spain}

On June 12, 2006, the Executive Board of the International Monetary Fund (IMF) concluded the Article IV consultation with Spain. ${ }^{1}$

\section{Background}

With growth of 3.4 percent in 2005, Spain continued its prolonged economic expansion. Over the last year, the economy created more than 60 percent of all new jobs in the euro area, accommodating large immigrant inflows and rising female labor force participation while unemployment declined further. Domestic demand-notably consumption and investment in construction, and more recently equipment-remained the main pull on activity, supported by employment and housing wealth gains. In contrast, net exports increased their negative growth contribution to some 2 percentage points. Growth was concentrated in nontradables, with sectors exposed to foreign competition experiencing little gain. Advance indicators point to some gradual softening of consumption and housing market inflation, amidst overall still buoyant activity in the short term.

Despite recent interest rate hikes, liquidity and credit conditions remain expansionary, with real interest rates negative or close to zero. Private sector credit grew at over 20 percent, spearheaded by real estate lending, and household indebtedness rose to over 110 percent of disposable income by end-2005. Headline and core inflation differentials with the euro area widened to 1.8 and 1.6 percent respectively in the first quarter of 2006 and unit labor cost growth, while slowing down, remained above the euro area average.

The external position deteriorated further in 2005, with the current account deficit reaching $71 / 2$ percent of GDP. Financial institutions intermediated external savings to meet the increasing

\footnotetext{
${ }^{1}$ Under Article IV of the IMF's Articles of Agreement, the IMF holds bilateral discussions with members, usually every year. A staff team visits the country, collects economic and financial information, and discusses with officials the country's economic developments and policies. On return to headquarters, the staff prepares a report, which forms the basis for discussion by the Executive Board. At the conclusion of the discussion, the Managing Director, as Chairman of the Board, summarizes the views of Executive Directors, and this summary is transmitted to the country's authorities.
} 
financing need of the nonfinancial private sector, mainly through the issuance of mortgagebacked securities in euro-area markets. Net external liabilities reached 46 percent of GDP.

Buoyant revenue drove the 2005 general government budget into a surplus of 1.1 percent of GDP, the first since the 1970s. However, non-interest spending (adjusted for one-time operations recorded in 2004) rising by 0.3 percentage points of GDP. As a result, fiscal demand withdrawal was insufficient to offset loose monetary conditions. Budget and spending plans for 2006-07 also imply a moderately expansionary stance. The Budget Stability Law and financing arrangements with the regions are undergoing reform. These reforms aim at increasing the cyclical flexibility of the fiscal rules and regions' ownership and co-responsibility, while also expanding the leeway afforded to territorial governments, with greater reliance on peer pressure to achieve budgetary discipline. Age-related fiscal costs are set to rise considerably over the longer term, with the onset of pension system deficits staring during the next decade.

The authorities' National Reform Program under the Lisbon agenda aims to raise per capita incomes and employment rates, by improving Spain's productivity performance, which has lagged behind internationally, and enhancing other determinants of competitiveness. Reforms implemented in recent years in labor and product markets have improved their flexibility. Nevertheless, distribution and retail, and other services, and domestically-oriented industries account for most of the inflation differential and remain sheltered by significant regulatory and administrative barriers to competition. The authorities are introducing a labor market reform package that will temporarily ease conversion of temporary labor contracts into special openended contracts with comparatively low dismissal costs and fiscal incentives, while strengthening restrictions for temporary contracts. No change is envisaged for regular open-ended labor contracts.

The FSAP found that the financial system is dynamic, profitable, professionally managed, and under strong supervision. The system is characterized by a high degree of financial intermediation, wide access to financial services, and low intermediation margins. The payments and securities' settlement systems were deemed robust and well integrated internationally. The financial system has been able to withstand substantial shocks, such as the financial disruption in Latin America of a few years ago. The FSAP recommended exercising vigilance with respect to developments in the mortgage market; bolstering the independence of financial sector supervisors; improving governance and market discipline of savings banks; and adopting a conservative treatment of financial institutions' industrial participations under Basel II.

\section{Executive Board Assessment}

They welcomed the continued strong growth performance of the Spanish economy, marked by robust job creation that has accommodated large immigrant flows into the labor market, a concomitant rapid income catch-up to euro area levels, and a solid fiscal position. They commended the authorities for the implementation of reforms since the early 1990s that have underpinned this performance, by opening the economy, enhancing its flexibility, and establishing stability-oriented policy frameworks.

Directors considered that short-term growth prospects remain buoyant and well above the euro area average, with some moderation in domestic spending as a result of rising interest rates likely to be compensated by stronger demand for Spanish exports. At the same time, however, the 
already large current account deficit is projected to widen further. In this regard, Directors cautioned about the possible adverse implications for the medium-term outlook of the continued erosion of Spain's competitive position, which has been driven by a persistent price and cost differential and-more fundamentally-weak productivity growth. A number of Directors also noted the risk of a more pronounced domestic demand slowdown prompted by private sector balance sheet consolidation, as households reduce their high indebtedness and/or real estate valuations correct.

Against this background, Directors supported the authorities' National Reform Program (NRP), which focuses on improving productivity, market flexibility, and competitiveness. They stressed that regaining competitiveness within EMU will require building on the NRP through the implementation of bold supply-oriented structural reforms.

As the NRP is implemented, Directors called for greater emphasis on competition-based incentives to enhance the role of the private sector in research and development, and on further deregulating sheltered sectors, with the removal of administrative and regulatory barriers to competition in distribution, energy, transport, and other services. In distribution in particular, productivity gains have been low by international standards and the inflation differential large due to a range of barriers to entry. Directors welcomed steps to strengthen the competition authority, and advised that these be complemented by procedures that ensure the full independence of sectoral regulatory agencies. Directors noted that an open approach to competition has served Spain well for many years, and called for it to be continued-in close collaboration with the European Commission-as the EU internal market extends to more sensitive areas.

Directors welcomed the continued improvement in labor market performance, on the heels of labor market reforms implemented over the past decade, but noted that there is scope for greater labor market flexibility. They considered that the recently announced reform of labor contracting provides some practical incentives for reducing Spain's relatively high incidence of temporary contracts. At the same time, a lasting reduction in the high share of temporary employment will require reducing the rigidity and high dismissal costs of regular contracts-which are left unchanged in the recent reform. Directors encouraged the social partners to review the collective wage bargaining system in order to better link wage and productivity increases across industries, firms, and regions, and to promote greater labor mobility.

Directors commended the authorities for achieving an appreciable fiscal surplus, continuing to accumulate resources in the Pension Reserve Fund, and reducing public debt-a good example of policies conducted in compliance with the revised Stability and Growth Pact. They noted, however, that the 2005 fiscal surplus stemmed largely from the buoyancy of revenues, while expenditure growth remained high, especially at the regional level, adding to demand pressures. Against this background, Directors supported the authorities' intention to allow the full play of revenue stabilizers, and generally recommended that this be accompanied by greater spending restraint at all levels of government. Some others were more cautious about the need for further fiscal tightening at this time.

Directors welcomed the greater flexibility and cyclical sensitivity of the new Budget Stability Law (BSL). They stressed that continued budget discipline within Spain's highly decentralized fiscal system requires a robust budgetary framework. In this regard, some of the BSL's features entailed a risk of insufficiently ambitious targets in good times. Directors stressed the importance 
of continued progress in enhancing accountability through improvements in public reporting and transparency, particularly at the territorial government level. In this vein, Directors recommended that the ongoing review of regional financing arrangements aim to strengthen fiscal coresponsibility by matching the decentralization of competencies with greater taxing powers for territorial authorities - and providing incentives to use these powers - thus avoiding reliance on increased transfers from the central government.

Directors noted Spain's relatively high fiscal costs of an aging population, and welcomed the steps forward contained in the recent tripartite agreement on pension reform, including incentives to extend the effective working life and the minimum contribution period. Placing the pension system on a long-term sustainable path will require further steps, including changes to key parameters such as the pension computation period. Containing rising healthcare spending will also require reform measures.

Directors welcomed the FSAP assessment that the financial sector is highly dynamic, well capitalized, profitable, and operating under strong supervision. Directors concurred that the main risks relate to the ongoing rapid credit growth connected with the housing market boom. They commended the adept supervision of the Bank of Spain. They recommended that the authorities monitor credit quality closely and exert careful vigilance on rapidly growing new credit vehicles, such as nonconventional mortgages. Directors looked forward to steps to strengthen the independence of financial regulators - most particularly that of the insurance supervisor. They emphasized the importance of preserving the current centralized prudential supervision and regulation system. Directors encouraged the authorities to foster strong governance of Spain's savings banks, including through supporting the issuance of instruments that enhance market accountability and reducing the ceiling on government representation on their boards of directors. A number of Directors, noting the size and concentration of industrial participations in some credit institutions' portfolios and related risks, recommended that the most conservative approaches under Basel II be applied to such participations.

Directors commended Spain's commitment to double its official development assistance allocation by 2008 , ultimately aiming at reaching the UN target. They urged the authorities to contribute, within the EU, to a successful completion of the Doha round.

Public Information Notices (PINs) form part of the IMF's efforts to promote transparency of the IMF's views and analysis of economic developments and policies. With the consent of the country (or countries) concerned, PINs are issued after Executive Board discussions of Article IV consultations with member countries, of its surveillance of developments at the regional level, of post-program monitoring, and of ex post assessments of member countries with longer-term program engagements. PINs are also issued after Executive Board discussions of general policy matters, unless otherwise decided by the Executive Board in a particular case. The Staff Report for the 2006 Article IV Consultation with Spain is also available. 
Spain: Selected Economic Indicators, 2001-06 1/

\begin{tabular}{|c|c|c|c|c|c|c|}
\hline & 2001 & 2002 & 2003 & 2004 & 2005 & 200621 \\
\hline \multicolumn{7}{|l|}{ Real economy (change in percent) } \\
\hline Real GDP & 3.5 & 2.7 & 3.0 & 3.1 & 3.4 & 3.3 \\
\hline Domestic demand & 3.6 & 3.3 & 3.8 & 5.0 & 5.3 & 4.5 \\
\hline HICP (average) & 2.8 & 3.6 & 3.1 & 3.1 & 3.4 & 3.4 \\
\hline Unemployment rate (in percent) & 10.6 & 11.5 & 11.5 & 11.0 & 9.2 & 8.6 \\
\hline \multicolumn{7}{|c|}{ Public finance (general government; in percent of GDP) } \\
\hline Overall balance & -0.5 & -0.3 & 0.0 & -0.1 & 1.1 & 0.9 \\
\hline Primary balance & 2.1 & 2.1 & 2.1 & 1.7 & 2.7 & 2.5 \\
\hline \multicolumn{7}{|l|}{ Interest rates } \\
\hline Money market rate & 4.4 & 3.3 & 2.3 & 2.0 & 2.1 & $\ldots$ \\
\hline Government bond yield & 4.9 & 4.6 & 3.5 & 3.6 & 3.1 & $\ldots$ \\
\hline \multicolumn{7}{|l|}{ Balance of payments (in percent of GDP) } \\
\hline Trade balance & -5.7 & -5.0 & -5.1 & -6.4 & -7.6 & -8.3 \\
\hline Current account & -3.9 & -3.3 & -3.6 & -5.3 & -7.4 & -8.1 \\
\hline \multicolumn{7}{|l|}{ Fund Position (as of March 31, 2006) } \\
\hline Holdings of currency (in percent of quota) & & & & & & 88.85 \\
\hline Holdings of SDRs (in percent of allocation) & & & & & & 72.40 \\
\hline Quota (in millions of SDR) & & & & & & $3,048.90$ \\
\hline \multicolumn{7}{|l|}{ Exchange rate } \\
\hline Exchange rate regime & \multirow{2}{*}{\multicolumn{6}{|c|}{$\begin{array}{l}\text { Euro Area Member } \\
\text { US } \$ 1.29140 \text { per euro }\end{array}$}} \\
\hline Present rate (May 12, 2006) & & & & & & \\
\hline Nominal effective rate $(2000=100)$ & 72.5 & 74.2 & 76.8 & 77.6 & 76.3 & $\ldots$ \\
\hline Real effective rate $(2000=100)$ & 85.2 & 88.8 & 92.6 & 94.4 & 94.3 & \\
\hline
\end{tabular}

Sources: INE; Bank of Spain; IFS; and IMF staff estimates.

1/ Figures for 2006 are Fund staff projections.

2/ Real national accounts variables are computed at constant 2000 prices. Thus, they might differ from the official national accounts data which, since 2005 , use a methodology based on chained-linked volume indices. 


\section{Statement by Moises Schwartz, Executive Director for Spain and Pablo Moreno, Senior Advisor to Executive Director June 12, 2006}

The Spanish authorities welcome the candid and constructive dialogue held with the staff during the Article IV and FSAP missions. The staff's high quality set of papers provide a useful contribution to the economic policy debate and the ongoing reform agenda; the authorities will take careful note of their comments.

\section{A. ARTICLE IV}

The staff analysis and policy recommendations are consistent with the authorities' assessment. There is coincidence on the diagnostic: the Spanish economy is registering high levels of growth and employment creation, and the short-term outlook is favorable with an expected lower but more balanced growth pattern. There is also a shared concern on the sustainability of longer-term growth, should the large inflation differential with the Euro-area and the lagging productivity growth remain. The main difference on the diagnostic refers to how much the current account deterioration is considered a sign of loss of competitiveness.

There is also agreement on the policy recommendations. The authorities policy framework is structured around three basic axes ${ }^{1}$ : (i) strengthening budgetary stability,(ii) improving the competitive environment and enhancing productivity, and (iii) greater transparency and quality of the regulatory framework. This economic policy strategy is oriented at maintaining the high levels of employment creation while achieving at the same time a more balanced growth pattern with less dependence on private consumption and the real estate sector, by boosting productivity growth and competitiveness.

The staff's recommendations coincide with this policy framework. The difference with the authorities is primarily a question of timing and pace. Particularly, the staff's assessment mainly refers to the first two pillars, calling for greater fiscal consolidation and a faster pace of reform. The authorities welcome the shared analysis and continue to work on the basis that there is always room for improvement and no room for complacency. This being said, we would stress that no-small progress has been achieved so-far.

We would highlight the following considerations on three different areas to qualify the staff's sense of urgency: (a) outlook, (b) fiscal policy, and (c) structural reforms.

\section{(a) A more benign outlook}

In 2005 the Spanish GDP has grown at a rate of 3.4 percent, significantly above Euro-area average. Unemployment has continued its downward trend, and it is now at 9.07 percent, below that of other major European economies. For 2006, both, the staff and the authorities, are projecting GDP growth at 3.3 percent. However, the authorities are expecting a more balanced growth pattern, with consumption moderating its growth, and increased dynamism

\footnotetext{
${ }^{1}$ See 2005-08 Stability ProgramUpdate:http://ec.europa.eu/economy_finance/about/activities/sgp/scplist_en.htm
} 
of investment in equipment (in line with its accelerated path of the last year and a half), and exports $^{2}$. The latest data on exports on the first quarter of 2006 already points into this direction with export growth accelerating to 9.1 percent year on year (the highest growth rate since 2000). As a consequence, the drag on growth from net exports has somewhat moderated in the last few quarters

Notwithstanding an element of loss of competitiveness, the deterioration of external accounts also reflects a cyclical component, the weak demand on traditional export markets, and an intense investment process. Several elements should be considered when assessing the current account:

- The authorities estimate that up to 44 percent of the deterioration of the trade deficit in 2005 is explained by the upturn in oil prices.

- The recovery of exports during the first quarter of 2006 has come hand in hand with an improvement of Spain's traditional markets, a diversification of its target markets and a better performance of competitiveness vis-à-vis non-EU OECD countries in the last few months ${ }^{3}$. All this together might evidence that Spain is regaining competitiveness..

- The current account deficit has been accompanied by an intense investment process, which is part of the catching up process of the Spanish economy. The investment-to-GDP ratio has increased from an average of 26.6 percent for the period 00-03 to an average of 28.7 percent for 04-05, while the Euro area average has decreased (from 20.7 percent to 20.4 percent) for the same period. At the same time, the savings-to-GDP ratio in Spain continues to be high, well above the Euro area average (22.4 percent vs. 20.9 percent, respectively). In part, this is due to the public sector surplus, which is, in fact, reducing the economy's borrowing requirement.

- Finally, being a member of the Euro area mitigates the risks linked to a current account deficit, since the aggregate exchange rate risk stemming from an individual member is practically eliminated. In addition, a common currency facilitates capital movements within the monetary union, making it easier to finance current account deficits, specially when, as in this case, the Spanish deficit only represents a 0.3 percent of the GDP of the Euro area and 6 percent of its savings.

The authorities are confident that inflation in 2006 will remain within the range of the Consensus Forecast [3.0, 3.5] .However, as staff points out, prices so far have been showing worrying dynamics this year, specially due to the evolution of oil prices ${ }^{4}$, with mixed results observed during the first five months of 2006. Our authorities are following these developments closely and believe that the combination of a better balanced pattern of growth, the effects of the recent appreciation of the Euro, and the measures to increase competition

\footnotetext{
${ }^{2}$ Official macroeconomic figures on the different components of the GDP can be downloaded from INE: http://www.ine.es/daco/daco42/daco4214/tabcntr.xls (table 11b).

${ }^{3}$ Competitiveness Tendency Index. $1^{\text {st }}$ quarter 2006 Report. Ministry of Industry, Tourism and Trade

${ }^{4}$ Greater oil price-developments incidence on Spanish prices is derived from both Spain's relatively high oildependency ratio and a quite dynamic domestic demand.
} 
and to make markets more flexible can lead to a more benign inflation forecast. Moreover, real salaries in Spain have decreased in 2005, for a second year in a row, in an amount comparable to that of Germany, the country in the Euro area with the best behavior on salaries.

\section{(b) Fiscal policy}

Unprecedented commitment to fiscal surplus. The 2005 general government budget closed with a surplus of 1.1 percent of GDP. Placing this number into context: (i) historically, it is the first surplus of the public administration in the past three decades of democracy, (ii) in the Euro-area, Spain is one of only three countries that have reached a surplus in 2005 . In cyclically-adjusted terms, these numbers imply a restrictive stance in 2005 measured by the structural balance. Here, the authorities disagree with the staff's assessment of procyclicality ${ }^{5}$.

Last Friday June the $2^{\text {nd }}$, the government approved the medium-term objectives of budgetary stability, setting the target of a fiscal surplus through 2009. This will imply an unprecedented five consecutive years of fiscal surplus for the public administration. In parallel, the authorities will attend expenditure needs arising from immigration (which has pushed population growth up to 10 percent in only six years), and those related to innovation, human capital formation, and infrastructure investment in order to enhance a productivity-based growth.

We are unconvinced by the staff argument to use fiscal policy and, more specifically, expenditure restraint, to ease short term imbalances. We would stress that the level of public expenditure is relatively low: the expenditure to GDP ratio in Spain is 38.2 percent, 9 points below the Euro-area average, making it one in only two countries (together with Ireland) with ratios below 40 percent. Furthermore, even the staff calculations point to the limited impact of falling expenditures on improving the current account balance ${ }^{6}$.

Be that as it may, the authorities have recently announced their commitment to contribute to a more balanced growth pattern via the introduction of an expenditure cap. According to this measure, public expenditure growth within the 2007 budget will be limited by nominal GDP growth, thus ensuring both a public surplus in 2007 and financial leeway in the years to come.

\footnotetext{
${ }^{5}$ The structural deficit indicators capture the impact of discretionary measures not linked to the cycle. Using only the behaviour of public expenditure-as the staff does-to gauge the orientation of fiscal policy may be misleading as it assumes that all expenditure growth is expansionary and any reduction is contractionary, irrespective of the final impact on the balance or the cyclical situation. We would also highlight that in 2005 , expenditures have grown in line with nominal GDP growth, thereby sustaining the fiscal the surplus. Contrary to the staff assessment, the OECD has qualified the fiscal stance in 2005 as moderately restrictive.

${ }^{6}$ Box 3 estimates that the impact of a 1 percent reduction on real expenditure would only yield a $0.15-0.16$ improvement in the current account. With this numbers, any significant result in the current account would require a very large expenditure reduction.
} 
Anchoring the fiscal consolidation framework. In 2005 and 2006 the government has been working on three major fiscal reforms: the new Budget Stability Law (BSL), the income tax reform, and the pension reform, which shall further anchor a fiscal framework in the main following directions:

- The new BSL, to enter into effect in 2007, strengthens the cyclical flexibility and corresponsibility of the fiscal framework by setting the target of a fiscal balance over the cycle for all levels of government, while safeguarding the social security system, which will remain on its current separate accounting. The BSL addresses previous legal inconsistencies as it complies with the principle of financial autonomy recognized in the Constitution to the regions. The new system is born with widespread support across national and regional parties and will be based on a consensual and coordinated approach, with regional ownership of fiscal stabilization. The BSL establishes as the general rule that Autonomous Communities will hold a balanced or in surplus budget (regional fiscal surpluses are ensured in expansionary periods). The exception to the rule is to allow a cyclical deficit when national growth is below the reference level (2 percent).

- The ongoing income tax reform, now in Parliamentary procedure, introduces a more streamlined and efficient income tax. The reform envisages a reduction of the corporate tax rate (down to 30 percent and to 25 percent for small and medium companies) better aligning it to European levels. The personal income tax will be simplified with key features such as: reducing the number of brackets, setting a higher exempt minimum income, a uniform rate on savings, or lowering marginal rates.

- The government has announced on mid-May the agreement among partners on the social dialogue on pension reform. The agreement will conclude on a wide range reform on pensions in line with the commitments of the Pacto de Toledo reinforcing long-term fiscal sustainability, with measures such as prolonging the effective working life and the extension of the minimum affiliation period to compute pensions.

\section{(c) Structural reforms}

Setting a new forward-looking, comprehensive, and closely monitored reform system. The economic reform process is structured around two major programs launched in 2005: the Plan de Dinamización, and the National Reform Plan under the European Union Lisbon strategy ${ }^{7}$. These programs introduce a new system of economic reform based on the following main principles: (i) predictability, specific measures and timetables for reform are targeted, (ii) accountability, the programs identify the center responsible for carrying out the measures as well as transparent monitoring procedures, (iii) comprehensiveness, economic reform is understood as a process that affects the full range of economic activity including fiscal stabilization, product and labor market liberalization, provision of public goods

\footnotetext{
${ }^{7}$ The National Reform and the Plan de Dinamización and can respectively be downloaded at: http://www.lamoncloa.es/PROGRAMAS/PNR/PNREnglish/default.htm?idioma=en-GB , http://www.minhac.es/Portal/Prensa/En+Portada/2005/textos_plan_dinamizacion.htm, this page includes a full account of the measures undertaken during its first year of implementation.
} 
(infrastructure, education), government sponsorship of activities with positive externalities (R\&D, startup companies), or environmental protection, (iv) continuous review, the process of continuous monitoring and evaluation of reforms paths the way for new initiatives.

\section{Key measures have been achieved during the past year:}

- The government has made a point of ensuring that the labor market reform is based on a successful social dialogue as the best way to cement its effectiveness. A key issue addressed in the dialogue has been the very high incidence of temporary employment in Spain ${ }^{8}$. On May $9^{\text {th }}$, the government and the social partners have completed an agreement on labor market reform that sets the basis for the reduction of temporary employment through greater utilization of the contrato de fomento (the indefinite contract with the lowest dismissal cost). The agreement also establishes a reinforcement of the services in charge of active labor market policies.

- In its first year of implementation, the Plan de Dinamización has registered an 85 percent success rate in the number of initiatives carried out, which have focused on product and service markets ${ }^{5}$. Among the main measures undertaken we would stress: the modernization of the competition authority, with an independent and better funded National Commission of Competition to be established in 2007; final steps on the liberalization of telecommunications services; the establishment of new licenses on railroad transportation; a fast-track judicial procedure for the house rental market; or the beginning of operations of the national registry of rights of emission under the Kyoto protocol. According to its commitment on policies' continuous review and up-date, in March the authorities implemented an actualization of the Plan de Dinamización. Along these new guidelines, the above mentioned expenditure-cap and a reform on the mortgage law (currently under public consultation) are worth mentioning. Other measures on the pipeline include the liberalization of railroad transportation of cargo, and increased competition on the energy sector.

\section{Official Development Aid}

On official development aid, the authorities are committed to duplicate the amount of ODA as a share of GDP, in order to reach $05 \%$ of GDP by 2008 and ultimately achieve the UN goal of $0.7 \%$ of GDP in the near future.

\section{B. FSAP}

The Spanish authorities have very much appreciated the deep and fresh-perspective provided by the FSAP team on their analysis of the financial system. The staff concludes with a very positive assessment on the resilience and competitiveness of the financial system stressing its high degree of financial intermediation, efficient allocation of savings, high capitalization

\footnotetext{
${ }^{8}$ The graph on page 24 of the staff paper clearly reflects this problem, Spain appears as an outlier on temporary employment.
} 
and reduced risk-profile of its institutions, wide and competitive access to financial services, a well-regulated system, and a cutting-edge prudential supervisory framework.

The main risks to this positive scenario are associated to the expansion of credit to the housing and construction sectors, and to the developments in the housing market and the competitiveness of the Spanish economy. Nonetheless, the stress-tests indicate a strong resilience of the financial system to shocks in these markets, even under extreme case scenarios considered by the staff (beyond standard stress-testing). This resilience reflects the soundness of the financial position and the adequate risk management of credit institutions.

The authorities will take full account the staff's assessment and FSAP recommendations. We would nonetheless highlight the following considerations with respect to some of the specific proposals:

- The recommendation of delegation of more normative and sanctioning power to supervisory agencies does not fit into the Spanish legal system. The capacity to legislate the financial system and to approve and repeal licenses to institutions belongs to the public administration. Formally, the Bank of Spain does not belong to the Spanish public administration and therefore cannot legally be invested with such powers. The system does however establish a central role for supervisory agencies both in regulation and in licensing. The Ministry of Economy and Finance (ME) elaborates prudential rules and the supervisors independently enforce those rules and develop their detail through their own directives. License revocations are to be sanctioned by the Ministry only after proposal at the initiative of the supervisor.

Furthermore, beyond it being a legal constraint, the attribution of the regulatory power to the government is also a more efficient system in the case of Spain. In the absence of a single financial supervisor, the $\mathrm{ME}$ is the only institution which has a global view of the three financial sub-sectors (banking, insurance and securities) and the only one that can thereby ensure a consistent financial regulation. The Ministry is also the institution responsible for negotiating and transposing the EU legislation on financial services.

- The staff raises concerns on how the ongoing reform of the Estatutos of Autonomous Communities could affect prudential supervision and regulation. Here, the authorities would like to reassure that the current system safeguards a centralized prudential supervision and regulation system. Constitutional jurisprudence establishes that supervision and sanction on solvency matters belongs exclusively to the State.

- As noted by the staff on footnote 12 of the FSSA, the Ministry and the supervisors signed a cooperation agreement last February. This agreement addresses the staff recommendation on coordination among supervisors by creating a high level Committee on Financial Stability, which will hold its first meeting this week.

- On savings banks, the staff appropriately notes that they are well regulated and supervised institutions that compete in equal footing with banks. On their regulatory framework we would like to mention that, as stated in paragraph 12 of the FSSA report, 
savings banks can merge within and across Autonomous Communities. The staff also recommends promoting new means to raise high-quality capital, such as the issuance of cuotas participativas. The authorities agree that these securities can play a useful role and their promotion was in fact one the main reasons behind the 2004 regulation related to these instruments. The current framework provides savings banks with a high degree of legal certainty to strengthen their capital. In relation to the issue of corporate governance, important steps have been taken, including, the irrevocability of the mandate and reduction of the ceiling on public sector representation on the boards, and the obligation to publish an annual report on corporate governance for all savings banks issuing securities admitted to trading in official markets. 